\title{
LA SEMANA SANTA EN EL NACIONALCATOLICISMO: ESPACIO URBANO, ARTE E HISTORIA. EL CASO DE VALLADOLID (1939-1949)
}

\section{Holy Week in National Catholic Spain: Urban space, art and history in Valladolid (1939-1949)}

\author{
MARY VINCENT' \\ University of Sheffield \\ m.t.vincent@sheffield.ac.uk
}

Cómo citar/Citation

Vincent, M. (2017)

La Semana Santa en el nacionalcatolicismo: espacio urbano,

arte e historia. El caso de Valladolid (1939-1949).

Historia y Política, 38, 91-127.

doi: https://doi.org/10.18042/hp.38.04

(Recepción: 07/11/2016. Evaluación: 07/01/2017. Aceptación: 07/04/2017. Publicación: 10/11/2017)

\section{Resumen}

Este artículo analiza la reinvención de la Semana Santa en España tras la Guerra Civil. Aunque es claramente un «rito de victoria», la Semana Santa, festividad anual y popular, se convirtió en parte de la vida corriente de la Espańa provincial de la postguerra. El artículo examina el caso de Valladolid, sosteniendo que la Semana Santa desde el primer momento incluyó y sirvió a los intereses municipales y comerciales. Las liturgias de la Semana Santa ayudaron a definir un nacionalcatolicismo emergente, que proporcionó una alternativa al falangismo desde del momento mismo de la victoria. La cooperación en la revitalización de la Semana Santa del ayuntamiento, la diócesis y, en Valladolid, una institución cultural estatal como el Museo Nacional de Escultura, denotaba también una concepción de la política claramente

1 Traducción del inglés: Ángela Lavilla Cañedo. 
paternalista. La Semana Santa de Valladolid era un claro ejemplo de una tradición inventada qu encarnaba el colapso del tiempo histórico para evocar una Espańa católica e imperial. Esta aparente atemporalidad, con su "orden natural», permitió una recreación historicista de la España «eterna», que contrastó agudamente con el fascismo. En Valladolid, donde el arte barroco desempeñaba un papel clave en la reconstrucción de la Semana Santa, sirvió como un vehículo cultural para entrelazar ciertos valores estéticos y políticos. En su formalidad y su efecto teatral, la Semana Santa era totalmente característica del nacionalcatolicismo. Sin embargo, como transformación performativa, la Semana Santa asumió una plasticidad que le permitiría convertirse en el único «rito de victoria» que pudo sobrevivir a la dictadura.

\section{Palabras clave}

Ritos de victoria; nacionalcatolicismo; tradición inventada; Semana Santa; régimen de Franco.

\section{Abstract}

This article looks at the (re)invention of Holy Week in post-Civil War Spain. Although clearly a "rite of victory", Holy Week proved to be both durable and popular, a regular, annual event that became part of the social fabric of postwar provincial Spain. Taking the case of Valladolid, the article shows that Holy Week involved municipal and commerical interests from the start. The liturgies of Holy Week helped to define an emergent National Catholicism, which provided an alternative to Falangism from the very moment of victory. But the co-operation of town hall, diocese and, in Valladolid, a state cultural institution, the Museo Nacional de Escultura, also demonstrated a highly paternalistic conception of politics. Valladolid Holy Week was a clear example of invented tradition, collapsing historical time to evoke Catholic, imperial Spain. This apparent timelessness, with its "natural" social and religous order allowed a historicist recreation of "eternal" Spain, which contrasted sharply with fascism. In Valladolid, a key role was played by Baroque art. The article explores this mobilisation of Baroque art, which acted as a cultural shorthand for these intertwined aesthetic and political values. In its formality, its performance and display, Holy Week was entirely characteristic of National Catholicism. As an urban performance, however, Holy Week assumed a plasticity that allowed it change its meanings over time and to become the only "rite of victory" to survive the dictatorship.

\section{Keywords}

Rites of victory; National Catholicism; invented traditions; Holy Week; Franco regime. 
I. INTRODUCCIÓN. II. A TRAVÉS DEL TIEMPO. III. LA PUESTA DE ESCENA DEL BARROCO. IV. A TRAVÉS DEL ESPACIO. V. CONCLUSIÓN. BIBLIOGRAFÍA.

\section{INTRODUCCIÓN}

La Semana Santa, junto con las corridas de toros, se ha considerado desde hace mucho tiempo una festividad española por excelencia. Por una parte, los capirotes y las cruces de Semana Santa se convirtieron en una imagen estereotípica de la «Espańa eterna», plasmada en la teatral serie fotográfica España Mistica (1943) de José Ortiz Echagüe y reproducida continuamente en los noticieros del NO-DO². Por otra parte, estas ceremonias están consideradas por académicos como «ritos de victoria», es decir, «instrumentos de la memoria» que «recordaban los sacrificios de la Guerra y los pecados del periodo republicano, permaneciendo en el recuerdo y en las conciencias de los españoles» ${ }^{3}$. Sin embargo, este artículo analizará la Semana Santa dentro del contexto del tejido social de la España provincial de la postguerra, tanto en su faceta litúrgica como festiva, como manifestación de la restauración del orden social tras la Guerra Civil. Este artículo sostiene que en la ciudad de Valladolid la Semana Santa representaba una oportunidad para los intereses municipales y comerciales y también para el discurso ideológico católico. No se puede, entonces, entenderlo simplemente como un ejemplo más de la «fascistización» de las costumbres ${ }^{4}$. Por tanto, el artículo contribuye a una reevaluación del nacionalcatolicismo como ideología característica de España durante los años de la victoria. Entendido así, el nacionalcatolicismo mantenía una capacidad mobilizadora propia, en parte porque había surgido en circunstancias muy parecidas y al mismo tiempo en el que emergió el falangismo como partido de masas ${ }^{5}$. Como demuestra el caso de la Semana Santa en Valladolid, un nacionalcatolicismo emergente proporcionaba una alternativa al falangismo desde del momento mismo de la victoria.

En contraste con otros «ritos de victoria», la Semana Santa fue a la vez exitosa y popular. Su atractivo fue más allá de la retórica oficial, que hasta

\footnotetext{
Ortiz Echagüe (1943); Tranche y Sánchez-Biosca (2002): 557-579.

Arco Blanco (2007): 65.

Cf. Rina Simón (2015b); Hernández Burgos (2011).

5 Vincent (2015): 109-110.
} 
ahora ha sido el principal foco de atención en el análisis histórico. Giuliana di Febo inicialmente hizo una distinción entre «ritos de guerra» - fundamentalmente la sacralización de la guerra de los nacionales como "cruzada»- y «ritos de victoria», los cuales se centraban la autoridad carismática y en la figura del dictador ${ }^{6}$. Se ha prestado escasa atención al funcionamiento de estas ceremonias, particularmente en su papel como «instrumentos de memoria». Los ritos de victoria invocaban la historia de España deliberadamente, en parte para evocarla como «memoria». Hechos históricos, como la conquista del general Franco -o «liberación»— de España en la Guerra Civil, trascendieron. El «sacrificio» de la cruzada franquista se asoció a una conceptualización temporal ahistórica: durante la Semana Santa la historia de la redención cristiana se representaba en la Pasión de Cristo. Las celebraciones, por tanto, combinaban historia, teología y mitología a través de la temporalidad multidimensional que la noción de «instrumentos de memoria» parecía requerir.

Los «ritos de victoria» analizados por di Febo son hechos aislados que tuvieron lugar en 1939 -el larguísimo desfile de la victoria, la presentación de la espada de Franco al Cristo de Lepanto- - y que ejemplifican claramente la sacralización del poder dictatorial de Franco. Esta selección también muestra cómo esta denominación se usa como abreviación para expresar tanto la imposición absoluta de la victoria militar al final de la Guerra Civil como el ritualismo de un régimen que se definía en gran medida en base a grandiosas liturgias públicas. Estudios recientes han analizado estas liturgias en términos de «religión política», aplicando el modelo de la Italia fascista desarrollado por Emilio Gentile 7 . Aunque este modelo continúa siendo disputable, tanto dentro como fuera de Espańa, la estética fascista del "primer franquismo» fue secular y sacralizada, y sus rituales proporcionaron versiones alternativas a mitos cristianos como la redención. Los muertos falangistas se convirtieron en mártires - e incluso, en el caso de José Antonio Primo de Rivera, en redentores- y 1939 en el "año cero", lo cual supuso una reinvención tanto de las expresiones políticas como del calendario festivo ${ }^{8}$. La remodelación colectiva del espacio público tuvo lugar a través de uniformes, pancartas y saludos romanos que claramente aludían a la Italia de Mussolini. Estas estrategias eran consciente y deliberadamente modernas. De hecho, la exhibición de una dinámica fascista moderna era parte integral de sus objetivos políticos.

Sin embargo, otro espectáculo falangista tuvo fines claramente historicistas: por ejemplo, cuando la Sección Femenina se apropió del castillo de La

\footnotetext{
6 Febo (2002): 27-38, 145-160.

Box (2004): 142-60; Box y Saz (2011).

8 Box (2010); Rodrigo (2014).
} 
Mota para las celebraciones de la victoria en mayo de $1939^{9}$. La Mota acarreaba la asociación con la tierra y la historia de Castilla, la cuna de Espańa. Este hecho facilitó la reinterpretación falangista del pasado a través de la sacralización de ciertos eventos y la transformación de hechos históricos en espectáculos públicos. En «un círculo virtuoso que unió el pasado con el presente», y que terminó con el nacimiento de la «verdadera» España en el Nuevo Estado de Franco, la historia española se redefinió en términos míticos como «unidad de destino en lo universal», siguiendo la frase de José Antonio. El pasado histórico elegido como fuente de estos mitos falangistas - y tratado eficazmente como almacén de eventos, símbolos y héroes - era una combinación de Edad Media con Renacimiento. Esta ambigüedad se hizo manifiesta en la conmemoración del milenario de Castilla en 1943, que celebraba los mil años de la historia de Castilla según un pasado mitificado en torno a la figura semi-legendaria de Fernán González a través de una puesta de escena didáctica y envolvente $^{10}$. Tal y como ocurría con la apropiación de La Mota, aquellas personas que formasen parte de la celebración podrían experimentar los valores y la 'esencia' de este periodo legendario.

Esta idea de «esencia» era recurrente: el pasado contenía la «esencia» del presente, Castilla era la «esencia» de España. Durante los ańos de la victoria, la historia de Castilla la Vieja — que había votado por la derecha durante la Segunda República y había apoyado el levantamiento de julio de 1936- se utilizó para reforzar esta idea. Fiel a su naturaleza e historia, Castilla permaneció leal. Esta idea de fidelidad favoreció a las élites locales, que demostraron ser altamente fuertes a nivel municipal, pues volvieron a recobrar su posición después del paréntesis republicano ${ }^{11}$. Lo cual, por supuesto, no significó que las cosas no hubieran cambiado. La represión, el gobierno militar y el crecimiento de Falange, ahora institucionalizado como un único partido, fueron, entre otras, el legado de la Guerra Civil que supuso profundos cambios sociales y políticos ${ }^{12}$. Aunque gran parte del viejo tejido social permaneció relativamente intacto, viejas familias de terratenientes y clases medias profesionales - las fuerzas vivas - se unieron gracias a la guerra. De ahí el énfasis en la «reintegración» durante la postguerra, ya que las nuevas y viejas élites promovían la harmonía de un supuesto orden social natural — profundamente desigual - justificado por la historia y Dios. El lenguaje sobre la esencia histórica y el tiempo mítico estaba a la orden del día. Por ejemplo, un falangista

\footnotetext{
Richmond (2003): 38-51; Primo de Rivera (1983): 155-181.

Alares López (2011); (2016): 3-4.

Cazorla Sánchez (1999); (2000): 43-60.

12 Palomares Ibáńez (2001); (2002).
} 
vallisoletano elogió las procesiones de Semana Santa por su «[...] austero y disciplinado espíritu religioso», y "el sobrio y concentrado misticismo» que caracterizaba "el temperamento de este pueblo castellano»" .

La confusión de los límites entre historia y leyenda - tanto dentro como fuera de Castilla - fue un tema central en el nacionalcatolicismo y que resonaba mucho más allá de Falange. El medievalismo hollywoodense continuó, pero el referente histórico dominante utilizado para el Nuevo Estado fue el Barroco, referido tanto a la época como al lenguaje visual del catolicismo español $^{14}$. De hecho, Eugenio d'Ors —el intelectual catalán que trabajó como jefe nacional de Bellas Artes para Franco desde 1937- definió el Barroco no como un periodo histórico, sino como un estado o actitud mental que podría manifestarse a lo largo de la historia ${ }^{15}$. Esto era la «España eterna» y también un referente cultural esencial para el Nuevo Estado de Franco. El Barroco no solo encarnaba la grandeza católica e imperial, sino también las ideas de Hispanidad y el austero ascetismo que supuestamente ejemplificaba el «alma» española ${ }^{16}$.

Dentro del medievalismo falangista el Barroco jugó un papel como «construcción contemporánea [...] planeada para trascender el tiempo y evocar épocas doradas pasadas ${ }^{17}$. Sin embargo, el Barroco parecía más familiar $\mathrm{y}$ «naturalizado» en las iglesias, imágenes y procesiones litúrgicas en cada rincón de la geografía española. Después de la Cruzada, el renacimiento del catolicismo también convirtió al Barroco en un componente clave dentro de los «ritos de victoria». En raras ocasiones fueron estos eventos fenómenos aislados. Por el contrario, el nacionalcatolicismo se caracterizaba por la repetición de actos y conmemoraciones, inevitablemente tanto seculares como religiosas. Eran parte de una unión penitencial devocional que se había reafirmado fuertemente durante los primeros años del franquismo.

No es casualidad que las celebraciones de Semana Santa cobrasen un nuevo impulso justo después de la Guerra Civil y en un contexto muy distinto del que favorecía la «religion popular», teorizada por los que investigan la sociedad tradicional. Después de la victoria de Franco la «recuperación» de los rituales de Semana Santa se consideró como un acto de desagravio por los

13 Narciso García Sánchez, 2 de marzo de 1944, Archivo Municipal de Valladolid (en lo sucesivo, AMV), caja 468-9, doc. 74. Él admitió que algunas procesiones en el sur superaban a las de Valladolid «en riqueza y lujo ostensible».

14 Barreiro López et al. (2014); Richards (2005): 197.

15 Ors (1944).

16 Locker (2014); Febo (1987).

17 Barreiro López (2014): 716. 
pecados de la Segunda República ${ }^{18}$. En ningún sitio se hizo más obvio que en la ciudad castellana de Valladolid, donde las procesiones y liturgias de Semana Santa se reinventaron, más que recuperaron. Esto supuso el culmen de un proceso que había empezado durante la década de los años veinte bajo la iniciativa del arzobispo Remigio Gandásegui (1871-1937). Este proceso involucró desde sus inicios a las autoridades municipales y a una institución cultural estatal: el Museo Nacional de Escultura. La Semana Santa de Valladolid fue un claro ejemplo de una tradición inventada en la cual participaron colaborativamente, y de manera significativa, poderes cívicos y eclesiásticos. Las procesiones se presentaban como específicamente castellanas, y no solo en el presente, es decir, en la postguerra espańola, sino también en una España «eterna» e imperial. Estas celebraciones fueron extraordinariamente exitosas y en poco tiempo consiguieron una pátina de atemporalidad que no dejaba ver su recién creación.

\section{A TRAVÉS DEL TIEMPO}

Los ejércitos franquistas lucharon en la Guerra Civil en términos de Cruzada, y esta fue precisamente la característica mitificada por los ritos de victoria. Como señala di Febo, una guerra adornada con fines sobrenaturales se convirtió en una proyección mítica a lo largo del tiempo, una reconstrucción de enfrentamientos pasados - de la Reconquista en particular - y una anticipación de enfrentamientos futuros (y definitivos) ${ }^{19}$. Tal y como puede leerse en el póster de la victoria de Teodoro Delgado, con el galeón en segundo plano haciendo referencia histórica al Siglo de Oro del catolicismo español, «Espańa fue, es y será inmortal». El periodo del imperio, el descubrimiento, la Casa de Habsburgo y la Inquisición se inmortalizaron como un encuentro mítico entre el bien y el mal, tal y como había sido la "Cruzada». En una entrevista a la prensa en 1937, el mismo Franco declaró: «Nuestra Guerra es una Guerra religiosa; nosotros [...] somos soldados de Dios y no luchamos contra hombres, sino contra el ateísmo y el materialismo, contra todo lo que rebaja la dignidad humana, que nosotros queremos elevar, purificar [énfasis mío] y ennoblecer $\aleph^{20}$.

La creación del Nuevo Estado se tomó como una oportunidad para reforzar la nación, y se hizo a través de la «España eterna» a imagen y semejanza de

18 Richards (2005): 211-220; Vincent (2009): 237-238; 244-249.

19 Febo (2002): 35.

20 Franco Bahamonde (1943) [16 de noviembre de 1937]: 454. 
la Cruzada. A pesar del énfasis otorgado al año 1936 por historiadores e historiadoras, este hecho conlleva a decir que los ritos de victoria no pueden considerarse como fenómenos aislados. Por el contrario, estos ritos tenían lugar repetidamente, se renovaban generación tras generación y, con el tiempo, pasaban a incorporarse al tejido social de la vida local.

La reconstrucción ritualizada de la Pasión de Cristo durante la Semana Santa fue un claro ejemplo de un uso del tiempo en términos de ciclo repetitivo. Aunque la Semana Santa evoca eventos que tienen lugar fuera de un tiempo histórico y para las personas creyentes cuenta la historia de la redención del mundo, es también una celebración asociada a una estación concreta del año. La festividad central de la Pascua, junto con su predecesora la Cuaresma, define y conmemora la primavera en el calendario cristiano, reafirmando tanto la naturaleza cíclica y estacional de este tiempo sagrado como el calendario litúrgico, todavía vigente en los ańos cuarenta en España. La estructura de la semana también imponía una disciplina temporal concreta ya que los y las participantes tenían que asistir a liturgias y procesiones específicas, ser puntuales e ir vestidos con atuendos concretos. Esta repetición anual también convertía a la Semana Santa en un marcador del ciclo vital ya que se recordaba año tras $a_{n}{ }^{21}$. La naturaleza expiatoria de los cultos también los inscribía dentro del marco del tiempo vivido. Esto permitía que las personas creyentes penitentes expiasen aquellas acciones que les suponían una lacra o que volvieran a tener sus conciencias tranquilas. Los devotos que participaban en los cultos de Semana Santa lo hacían para poder acceder a los eventos trascendentales que estaban conmemorando. La inmanencia es el primer marco temporal de cualquier evento litúrgico y el tiempo litúrgico se define, en parte, por la repetición cíclica - y potencialmente infinita- de palabras, frases y gestos ${ }^{22}$.

Una noción similar a esta de tiempo cíclico y repetitivo se hizo evidente en varios ritos de victoria seculares, en particular la conmemoración anual de la victoria el 1 de abril que a menudo coincidía con la Semana Santa, como fue el caso del Miércoles Santo en 1942. Una vez que pasó el inicial, improvisado y hasta cierto punto caótico momento de victoria, estas conmemoraciones de la victoria altamente militarizadas se convirtieron en auténticos montajes, en actuaciones repetidas que jugaban un papel como actos de restablecimiento y de demostración de una continuidad de la «verdadera» España. De este modo también obtenían su significado, en parte, a través del acto de repetición, aunque también se especializaban cada vez más. En Valladolid, una de las sedes originales de las JONS y de donde era natural Onésimo

21 Por ejemplo, Gavilán Domínguez (2005): 7-8.

22 Spiegel (2002): 151-3. 
Redondo, Falange mantuvo una enorme presencia en los desfiles de la victoria y en las conmemoraciones de, por ejemplo, el mitin de 1933 en el Teatro Calderón, aunque principalmente aparecía representada en Semana Santa a través de una serie de bandas de música. De hecho, dentro de la documentación conservada en el archivo municipal, el partido queda practicamente invisible, sin papel alguno en la organización de la Semana Santa vallisoletana ni antes ni después del cambio de rumbo de la Segunda Guerra Mundial a favor de los aliados en 1943.

Falange no tenía el monopolio de la representación de la Espańa eterna. La Semana Santa era un tema central en las pequeñas ciudades históricas de Castilla y León y del sur. En las ciudades andaluzas, con sus «coloridas» tradiciones folclóricas y "animadas" procesiones, la restauración de la Semana Santa en el periodo de la postguerra marcó una vuelta a un orden "natural» que había sido interrumpido por la revolución anticlerical ${ }^{23}$. Pero Castilla la Vieja no había experimentado tal revolución. El orden "natural» que se exhibía era el de fidelidad al pasado, a las comunidades que habían permanecido fieles a su historia. De este modo, la Semana Santa proporcionó una oportunidad para afirmar una visión alternativa a la fascista, usando el lenguaje visual y los gestos de la Iglesia en lugar de los de Falange. La Semana Santa de Valladolid derrumbó explícitamente el tiempo histórico, con el fin de recobrar «aquel grandioso esplendor» de la España imperial del Siglo de Oro. Esto se realizó por medio del arte — vehículo de la verdad emocional y religiosa- el cual era una característica prominente de la Semana Santa en Valladolid ${ }^{24}$.

El recuerdo del arzobispo Gandásegui se evocaba frecuentemente durante la Semana Santa en los años veinte y treinta, en gran medida porque él había reconocido «este esplendente [sic] arte de pasión que supera el arte de la razón $»^{25}$. La recuperación de las procesiones tuvo lugar gracias a la estrecha colaboración entre la diócesis y el Museo Provincial de Bellas Artes (Museo Nacional de la Escultura, después de 1933) bajo la dirección de Juan Agapito y Revilla (1923-31) y Francisco de Cossío (1931-1959). En mayo de 1921 Gandásegui se dirigió al museo con la intención de averiguar si podrían usarse figuras individuales de la colección para reconstruir «con otras estatuas existentes en las Iglesias los antiguos pasos de Semana Santa» ${ }^{26}$. Siempre y cuando

23 Richards (2005): 211-20; Hernández Burgos (2011).

24 Los carteles de 1926 y 1927 llevaban las frases: «Es en el arte la primera de España» y «Triunfo del arte español», http://www.carteles-semana-santa.org/valladolid-capital,

25 Diario Regional (en lo sucesivo DR) 22 de marzo de 1939.

26 Actas de la Junta de Patronato, Museo Provincial de Bellas Artes de Valladolid (en lo sucesivo "Actas»), sesión celebrada el día 18 de marzo de 1921. 
no hubiera dudas sobre la propiedad, el museo estaba a favor y, de hecho, Agapito y Revilla llevó a cabo una meticulosa, y a menudo imaginativa, investigación histórica para establecer cómo podrían haber sido los pasos en su origen $^{27}$. La recuperación de la Semana Santa en Valladolid tuvo, por tanto, características distintivas. El centro de atención de la procesión estaba en grupos de imágenes, usadas para reavivar escenas de la Pasión. Esto estimuló un énfasis especialmente bíblico y catequístico ya que dichas imágenes podían circular con facilidad por la ciudad gracias al uso de plataformas con ruedas.

El ejemplo más claro de este énfasis catequístico fue el Sermón de las siete palabras, una meditación pública sobre las últimas siete palabras de Cristo desde la cruz realizada por Gandásegui en $1932^{28}$. El énfasis bíblico, junto con la restauración de los pasos y las tradiciones de las procesiones, ejemplificó precisamente el colapso del tiempo histórico en las liturgias de Semana Santa. Las procesiones evocaban eventos históricos concretos, en particular la crucifixión, pero también la Contrarreforma que se había celebrado así en primer lugar. La Semana Santa representaba una tradición cristiana continua, que unía la última semana de Cuaresma desde la antigüedad, pasando por la Contrarreforma hasta llegar al periodo contemporáneo. Otros periodos y eventos quedaban dentro de este marco de referencia, creando un interesante palimpsesto pues integraba a participantes y espectadores. Tal y como escribió Cossío en El Norte de Castilla — periódico del que era editor- «la tradición es en el fondo una cadena de familia». De ser truncada, sería difícil de recuperar, incluso donde «tenía las más fuertes raíces». Pero Gandásegui tuvo éxito ya que consideraba que "habría que crear no una procesión sino un espíritu». De este modo, la Semana Santa en Valladolid fue más que «una restauración»: «Esto significa encontrar de nuevo el cauce y entregarse en él a una corriente de tiempo que creíamos perdido ${ }^{29}$.

Las celebraciones de Semana Santa empezaban en Domingo de Ramos con una procesión infantil, popularmente conocida como "la Borriquilla», inusual tanto por su paso — de interés histórico, pero de poco mérito artístico- como por su falta de solemnidad ${ }^{30}$. En 1935 Gandásegui recuperó la procesión e inmediatamente gozó de popularidad. La entrada triunfal de Cristo en Jerusalén era el único momento de la Semana Santa que no estaba definido por la muerte; por tanto, la Borriquilla era un inicio apropiado para las liturgias y

27 Pasos restaurados (2000): 44-52, 64-72, 73-84.

28 Son, de hecho, frases: Lucas 23:34, 43; Juan 19:26-7; Marcos 15:34 (y Mateo 27:46); Juan 19:28, 30; Lucas 23:46.

29 "La tradición recobrada», El Norte de Castilla (en lo sucesivo NC), 21 de marzo de 1940.

30 Por ejemplo, DR 1 de abril de 1939. 
contrastaba especialmente con su culminación en la procesión del Santo Entierro en Viernes Santo, que a su vez también había sido recuperada por Gandásegui. La procesión de Viernes Santo, reorganizada en 1941 como una recolección de varias liturgias - y de la Pasión misma - con la participación de todas las cofradías y rebautizada como «la general de la Sagrada Pasión del Salvador», creció en número, complejidad y esplendor durante la década. Este fenómeno iba en consonancia con el patrón general observado en las liturgias durante la Semana Santa. El periodo de los primeros años de postguerra fue cuando la Semana Santa en Valladolid se inventó realmente: concebida por diferentes autoridades locales — sobre todo por Gandásegui- en los años veinte, consiguió un verdadero ímpetu después de la victoria en la Guerra Civil ${ }^{31}$.

La procesión de Viernes Santo de 1939 tenía todavía un cariz improvisado $^{32}$. Dos cofradías se fundaron ese año: la primera, La Oración del Huerto, solo pudo proveer con hábitos a algunos cofrades, y en la otra, El Descendimiento, no solo desfilaron sin hábitos, sino que al año siguiente aparecieron con atuendos poco convencionales que incluían "listados turbantes orientales» y velos que cubrían el rostro ${ }^{33}$. La Semana Santa se desarrollaba rápidamente. Dos nuevas cofradías, la Sagrada Cena y el Santísimo Cristo de la Luz, se unieron a la procesión de Viernes Santo en $1941^{34}$. Ese mismo año, las congregaciones jesuitas de los Kostkas y de los Luises, las cuales habían tenido en el pasado a Onésimo Redondo y Cossío entre su membresía, se fundaron como cofradías y llevaban la imagen de Cristo en la Columna en sus hábitos en lugar de trajes ${ }^{35}$. De manera similar, la congregación de trabajadores ferroviarios de la Sagrada Familia pasó a ser una cofradía en los años cuarenta. La Juventud de Obreros Cristianos formó su cofradía del Santo Cristo del Despojo en 1943 - y nunca cubrieron sus rostros-, y la Asociación Josefina fundó el Santo Sepulcro en $1945^{36}$. El año anterior, los soldados que tradicionalmente acompañaban al

31 El nuevo nombre también marcó el fin de la ambición de Gandásegui por estructurarse en torno al "Entierro de Cristo» de Juan Juni, que no era una imagen procesional y a lo que MNE se opuso.

$32 \quad D R, 5$ de abril de 1939.

33 DR, 22 de marzo; 14 de abril de 1941; este atuendo nada popular fue reemplazado por el hábito convencional en 1944; http://www.descendimientovalladolid.es/uniformidad.html.

$34 \quad D R, 31$ de marzo; 18 de abril de 1942; la Sagrada Cena fue fundada por un sacerdote.

35 DR, 18 de julio de 1943.

36 Cofradías que asisten a la procesión del Santo Entierro, AMV, Caja C.449-89, Doc. 7; Caja C.585-6, Doc 57, sin fecha, pero 1942 y 1943; la Sagrada Familia se convirtió en la Exaltación de la Cruz en 1944. 
eccehomo conocido como Cristo de la Caña también se habían convertido en una cofradía, el Santísimo Cristo de los Artilleros.

Este rápido desarrollo también se hizo patente a través de los numerosos adornos que acompañaban la procesión de Viernes Santo. Las autoridades civiles, militares y eclesiásticas, incluyendo Falange, siempre estaban representadas y en la procesión de 1940 aparecieron lideradas por la Guardia Civil montada ${ }^{37}$. El número de bandas de música aumentó, principalmente provenientes de las fuerzas armadas, Falange y, desde 1943, de la policía de Madrid. Los hábitos se uniformizaron y generalizaron. Las carrozas se reemplazaron y se añadió alumbrado eléctrico; por ejemplo, la Quinta Angustia de Gregorio Fernández se iluminó desde 1943 con "potentes focos y bengalas de colores ${ }^{38}$. Se proveyó de Guardias de honor para más imágenes, las cuales también aumentaron en número. En 1942 la nueva cofradía eucarística de la Sagrada Cena encargó un paso de dicha escena, mientras que la cofradía de las Siete Palabras —establecida por Gandásegui en 1929- incluyó un segundo paso del Cristo crucificado entre dos ladrones. Este "nuevo» paso fue bautizado provisionalmente «Et cum iniquis reputatus est» [Marcos 15:28] por el vicario general de la diócesis, pero fue finalmente identificado con la séptima y última "palabra» cuando la cofradía se hizo con todo el conjunto en $1975^{39}$.

La Semana Santa de Valladolid adoptó su forma actual entre los años de postguerra 1939 y 1945 . Se brindó gran cuidado con respecto a las tradiciones heredadas de las seis cofradías históricas de la Edad Moderna ${ }^{40}$. Sin embargo, gracias a la introducción de los pasos sobre ruedas, hubo un nuevo énfasis catequístico y bíblico que permitió agrupar imágenes aisladas de escenas de la Biblia. La ausencia de costaleros también significó que, a diferencia con el sur, los trabajadores se quedasen sin desempeñar un papel. Este ejemplo es solo una de las muchas maneras de diferenciar la Semana Santa vallisoletana de la andaluza. En Andalucía los niveles de práctica religiosa eran muchísimo más bajos y las corrientes anticlericales bastante más fuertes, sobre todo entre los

$37 D R, 23$ de marzo de 1940; 5 y 10 de abril de 1941; 2 y 4 de abril de 1942; 24 de abril de 1943; 8 de abril de 1944. NC 26 de marzo de 1941; 8 de abril de 1944; 31 de marzo de 1945.

$38 \quad N C, 24$ de abril de 1943.

39 DR, 24 de marzo de 1942; "Cofradía de las Siete Palabras: programa 1942», AVM, Caja C.585-6, Doc. 43-5; otras «palabras» se añadieron en 1944, 1954, 1959 y 1975. Los ladrones originales, de Gregorio Fernández, pertenecían al MNE; fueron reemplazados por copias en 1965 .

40 Todos fundados en los siglos xv y xvi; Burrieza Sánchez (2004). 
hombres de clase humilde. Estas diferencias dificultan el análisis de las celebraciones en Valladolid en términos de «religion popular» ${ }^{41}$. Faltan indicaciones de una religiosidad oposicional y heterodoxa regida por la Iglesia y el Estado; en contraste, la Semana Santa de Valladolid tenía un marcado tinte burgués, acentuado por un pronunciado corporativismo que reflejaba perfectamente la vida ciudadana de los primeros años del franquismo en España. Además de representar a cofradías de soldados y trabajadores ferroviarios, El Cristo de la Luz también era para el profesorado universitario, mientras que la Oración del Huerto representaba a pequeños agricultores y horticultores. Abogados y médicos estaban representados en la procesión de Jueves Santo "Caridad y Penitencia». El efecto intencionado era el de un cuerpo social en armonía, agrupado según ocupación, función y rango. La organización ritual e institucional de la vida ciudadana recreaba simbólicamente los gremios medievales tan enfatizados por la doctrina social católica y también el sindicato vertical del estado corporativo falangista, aunque el partido nunca fuese aludido directamente. A pesar de su importancia, Falange no era la única fuente de visiones laicas para la España franquista, incluso durante su época de mayor influencia. El corporativismo tenía versiones católicas y capitalistas además de fascistas.

Este aspecto ciudadano de la Semana Santa no solo era importante bajo un punto de vista simbólico, sino que también fue una parte integral de su éxito y permanencia. A diferencia de otras conmemoraciones y ceremonias franquistas, la Semana Santa se mitificó rápidamente como una celebración popular tradicional en las ciudades de España ${ }^{42}$. Las procesiones experimentaron profundos periodos de renovación tanto en los años cuarenta como en los setenta a pesar del marcado contraste en el contexto político. De hecho, en 2014, el ayuntamiento de Valladolid acordó por unanimidad hacer una petición a la UNESCO para que reconociesen la Semana Santa como Patrimonio Inmaterial de la Humanidad basándose en su «singularidad, plasticidad y autenticidad». Los concejales de hoy — del PP, PSOE e IE — manifestaron involuntariamente algo que sus ancestros habrían compartido. La Semana Santa era, según afirmaron, «intemporal, es actual y ha sobrevivido a todo en sus más de cinco siglos de historia, evolucionando pero manteniendo su esencia», palabras que testifican su éxito, es decir, su auténtico arraigo en la vida de la ciudad ${ }^{43}$.

\footnotetext{
41 El modelo empleado por Moreno (1985), y Rodríguez Becerra (2000).

42 Barthes (2009) [1957].

43 http://www.eldiario.es/cultura/Valladolid-Semana-Santa-patrimonio-mundial_0_247075673.html accedido el 21 de julio de 2016.
} 
El ayuntamiento se responsabilizó de la organización de la Semana Santa en 1941, proclamando ser la "única de su género en España» y no solo como una fuente de orgullo local, sino también como algo digno de ver ${ }^{44}$. Este también fue el año en el que el General Franco aceptó el puesto honorífico de Hermano Mayor del Descendimiento, mientras su mujer Carmen Polo - como Camarera Mayor en la cofradía histórica de las Angustias- observaba dicha procesión desde el balcón del ayuntamiento ${ }^{45}$. El ritual cívico jugaba un papel central en las ceremonias de Semana Santa, así como la correspondiente asociación con las autoridades gobernantes. El General Franco, como Hermano Mayor, estaba asumiendo un papel como monarca — la cúspide de la pirámide - tal y como lo había hecho Alfonso XIII antes de 1931 y como lo haría Juan Carlos desde los años setenta ${ }^{46}$. La restauración de la tradición monárquica auguraba el regalismo del régimen franquista después de 1945 y marcó la vuelta a un orden social jerárquico «natural».

Sin embargo, en 1941 la posición de Franco dependía del puro ejercicio del poder militar. A pesar del aumento de adornos reales, fue un dictador militar hasta su muerte, con la ayuda del ejército como significativa fuerza social y política. Rendir honores militares a imágenes religiosas era un tropo monárquico consolidado - Alfonso XIII había convertido a la Virgen del Pilar en capitana general del ejército- mientras que la presencia militar en las procesiones de Semana Santa durante los años cuarenta reflejaban la brutal realidad de la victoria ${ }^{47}$. Se podía observar esto en Valladolid con la reafirmación del Cristo de los Artilleros, ahora oficialmente una cofradía, aunque en este caso el énfasis retórico estaba puesto, de nuevo, en la tradición: los soldados de artillería habían acompańado al Ecce Homo «desde siempre». Hubo, sin embargo, una nueva formalidad y un énfasis en el rango, con la participación de «todos los jefes y oficiales» antes de los inicios de $1944^{48}$. El uso de la jerarquía era típico de los tiempos en los cual los soldados formaban parte de la vida de la ciudad como un cuerpo más.

Esta potente asociación ritual entre el ejército y el Jefe de Estado subraya los orígenes de la Semana Santa como «rito de victoria», como el duro contexto socio-económico. A pesar de la pompa, en 1941 las noticias sobre la Segunda

$44 \quad$ NC 26 de marzo de 1941.

45 DR 12, 14 de abril de 1941.

46 Sánchez Herrero (1992): 84-7.

47 Por ejemplo, la Cofradía de Cristo Mutilado de Málaga, y la Virgen de la Estrella, cuyo manto estaba bordado con una estrella por cada malagueńo perdido en la Legión Azul.

$48 \quad$ NC 8 de abril de 1944. 
Guerra Mundial — que incluían la inminente invasión de Gran Bretaña—y la epidemia de tifus en Madrid dominaban las columnas de El Diario Regional. La escasez de papel obligó al periódico a limitarse a una única página antes de los comienzos de mayo ${ }^{49}$. Sin embargo, paradójicamente, esta escasez pudo haber contribuido al éxito y perdurabilidad de la Semana Santa misma. Cuando el ayuntamiento se responsabilizó del evento — con el permiso y la colaboración de la diócesis y la Junta de Cofradías - no fue solo por un deber religioso o patriótico $^{50}$. Como con todas las festividades populares, la Semana Santa podría comercializarse. Esto brindaba una oportunidad de negocio que, además, en caso de ser aprovechada apropiadamente tendría ventajas para la ciudad.

El Norte de Castilla aseguraba que el programa de 1941 «traerá a nuestra capital un numeroso contingente de forasteros» lo cual conllevó a que un considerable esfuerzo fuera destinado a subrayar el potencial de la Semana Santa como atractivo turístico ${ }^{51}$. En 1941, el alcalde viajó a Madrid para publicitar las celebraciones en interés de la ciudad. Los deberes cívicos se unieron al orgullo local y a un mercantilismo bastante fuerte puesto que la municipalidad se esforzó por aprovechar al máximo esta oportunidad. Se crearon sellos, panfletos, folletos y modestas guías (llenas de anuncios de negocios locales) ${ }^{52}$. El Ayuntamiento, que ya había dado subvenciones a cofradías, elevó sus donaciones y también compró 6.000 palmas de un proveedor de Elche para la procesión infantil de la Borriquilla $^{53}$. Las fuerzas vivas trabajaban juntas por los intereses de la ciudad bajo una conceptualización de la política altamente paternalista. Las inversiones del Ayuntamiento mejorarían la presentación de las cofradías, «que desfilarán en mayor cantidad que en los años anteriores», y esperaban que facilitando altavoces al Via Crucis del Miércoles Santo fuese una manera en la cual las procesiones «este año, a más de mejor organización y perfección, serán aumentadas»" ${ }^{54}$.

La atención prestada a la procesión de Domingo de Ramos y a las estaciones del Vía Crucis a mitad de semana muestra la manera en la cual las autoridades seculares y eclesiásticas querían que la Semana Santa se ampliase. Esto conllevaría a un mayor gasto en la ciudad y también le proporcionaría una panorámica de la sociedad española. La ciudad no se limitaba a rezar. Algunas

Pérez López (1994): 158-159.

$50 \quad$ NC 26 de marzo de 1941; DR 16 de marzo de 1941.

$51 \quad$ NC 26 de marzo de 1941.

52 Ejemplos en AMV, Caja C.489-49; Caja 469-25.

53 «Semana Santa: donativos a Cofradías», AMV Caja 380-48; DR 3 de abril de 1941; Correspondencia entre la diócesis y Vicente Navarro Maciá, Cosechero de Palma Blanca, AMV Caja C.489-49, documentos 12, 13, 17.

$54 \quad D R 16$ de marzo de 1941. 
de las celebraciones oficiales eran marcadamente seculares, e incluso frívolas. Por ejemplo, en 1941 el Ayuntamiento organizó una "grandiosa función de gala» en el Teatro Calderón el sábado por la tarde, con corridas de toros la tarde del día de Domingo de Resurrección, seguidas por bandas militares que tocaron en el Campo Grande a la hora del paseo ${ }^{55}$. Con la excepción de las corridas de toros, estas eran diversiones caras y burguesas, aunque antes del comienzo de 1944 los cines locales también anunciaban los últimos estrenos de Holywood para el Sábado Santo ${ }^{56}$. En términos teológicos este final secular no tenía ningún sentido ya que la historia de Pascua - con su significado redentor- termina con la resurrección de Jesús. Pero la Semana Santa en España terminaba tradicionalmente, como el Vía Crucis, con la muerte y entierro de Cristo ${ }^{57}$. Las autoridades cívicas siendo muy prácticas usaron la fiesta de resurrección para promocionar oficialmente una fiesta secular que se parecía a las romerías de los pueblos tanto en su cronología como en su estructura.

Estos entretenimientos familiares municipales tenían un claro propósito social y comercial. Sin embargo, en términos políticos, eran muestra de una cultura de "despolitización» normalmente más asociada con una etapa de desarrollo más tardía de la dictadura que surgió después de que el hambre y la brutal represión de los años cuarenta acabase. No obstante, la participación del Ayuntamiento de Valladolid en la Semana Santa siempre fue en términos comerciales y turísticos, de manera que pudieran asegurar el mayor número de ingresos durante una semana al año. Esto respondía a una necesidad ya que en 1944 parecía existir el acuerdo de que «nuestros desfiles procesionales precisan una propaganda mayor de la que hasta la fecha han tenido ${ }^{58}$. A pesar de las abundantes campañas publicitarias, la actividad aumentó de nuevo en 1944, el mismo año en el que la Casa de Valladolid abrió en Madrid, y sirvió como punto de referencia para las campańas de Semana Santa ${ }^{59}$. El Ayuntamiento, además de la distribución de material publicitario sobre España, encargó anuncios para el cine y la radio, e invitó a las procesiones a periodistas (que incluían a editores de $Y a$, Pueblo y $A B C$ ) que iban a cargo del erario ${ }^{60}$. En

NC 26 de marzo de 1941; DR 16 de marzo de 1941.

56 NC 9 de abril de 1944.

57 La procesión de Domingo de Pascua data de 1960 pero la cofradía de Jesús Resucitado se había fundado en 1950.

58 De Narciso García Sánchez, presidente de la Asociación de la Prensa local, al Delegado Nacional de Propaganda 2 de marzo de 1944, AMV, caja 468-9, doc. 74.

59 Amigo Vázquez et al. (2007): 217-219

60 Correspondencia, AMV, Caja 468-9, Doc 5, 15, 24, 25, 39, 40, 72; «Semana Santa 1944", AMV, Caja 469-25. 
las palabras de un corresponsal: «Hemos de trabajar para que nuestras Procesiones ocupen en España el lugar que las corresponde; por su Arte y Religiosidad, y además, por su presentación.... ${ }^{61}$.

\section{LA PUESTA DE ESCENA DEL BARROCO}

En 2014 cuando el Ayuntamiento solicitó reconocimiento a la UNESCO hizo referencia explícita a la "colección viva del barroco castellano» de la ciudad, una colección procesional única a la que El Norte de Castilla había descrito como «la culminación del arte imaginero castellano»" ${ }^{62}$. Esta aparente unanimidad, a lo largo de varias décadas y contextos políticos irreconociblemente distintos, demuestra el peculiar papel que el barroco jugó en la invención de la tradición de la Semana Santa de Valladolid. Sin embargo, a pesar de la riqueza de las colecciones de la ciudad, incluso una somera lectura de la prensa de los ańos cuarenta, las guías de museos, o las abundantes críticas artísticas, culturales e históricas, muestra la manera en la que solo dos artistas, Juan de Juni (1506-77) y Gregorio Fernández (1576-1636), se tuvieron en cuenta para representar a toda la tradición.

Esto reflejaba, en parte, su habilidad, pero ambos estaban íntimamente unidos a Valladolid: Juni era el extranjero que había llegado y había hecho suya la ciudad — «el imaginero francés capta el alma de los labriegos de la tierra llana»— y Fernández había pasado toda su vida ahí. Se creía que ambos podían acceder a lo sublime. Las Angustias de Juni - que creó cuando era miembro de la cofradía - era «divinamente humana»; la belleza de la Dolorosa de Fernández era insuperable como imagen hecha «de mano del hombre» ${ }^{63}$. La veneración hacia estos dos artistas no era nada nuevo. Se les consideraba, de manera indiscutible, los maestros de la forma y fundadores de una tradición específicamente castellana en las artes plásticas religiosas, algo totalmente complementario en sus logros. Según Agapito y Revilla, Fernández era tanto el sucesor como la antítesis de Juni: «A su movilidad y violencia opónense la compostura y dulzura... no busquéis en Fernández esos rostros violentos y esa exagerada energía de Juni; buscad, sí, tranquilidad y reposo... sentimiento y ternura... la idea piadosa que hace mover su mano» ${ }^{64}$.

61 Copia de carta en papel carbón, sin firma ni fecha AMV, Caja 468-9, doc. 3.

$62 \quad$ NC 24 de abril de 1943.

63 García Chico (1949): 32; (1952): 21.

64 Agapito y Revilla (1913): 365. 
Todas estas consideraciones - ya fueran de curas, periodistas o historiadores del arte- se fundamentaban en la idea de que las creencias religiosas eran las creadoras del arte religioso barroco. El valor teológico se reflejaba en —o incluso dependía del — valor artístico. La tradición barroca de representar la corporalidad de manera muy acentuada permitía crear al artista un momento de «síntesis estética y religiosa» que permanecía congelado en la imagen que había desarrollado ${ }^{65}$. La extraordinaria corporalidad de las imágenes creadas por los imagineros del barroco español, a diferencia de las esculturas medievales o de los iconos de la Iglesia Ortodoxa, parecía negar la materia con la cual estaban hechas ${ }^{66}$. Madera policromada, vidrio, corcho, cuerno y pelo se transformaban en carne humana de manera que la imagen se confundía no solo con el objeto de devoción sino también con su parecido original. Dos leyendas sorprendentemente similares rodearon al Cristo Crucificado de Juni y al Cristo Atado a la Columna de Fernández. Se dice que cuando Juni terminó el crucifijo - «uno de los Crucifijos más hermosos, humana y divinamente hermosos, de la escultura policromada castellana» — el artista exclamó « $\mathrm{O}$ divino Jesús mío! Ese cuerpo que aquí contemplo yo lo hice pero la cabeza es obra tuya ${ }^{67}$. En el caso del Cristo de Fernández, la propia imagen fue la que habló. Mientras el escultor, inmóvil, observaba su obra con deleite, confundiendo las categorías de humano e imagen, oyó al Cristo preguntar: ¿dónde me miraste que $\tan$ bien me retrataste? Por supuesto, la respuesta fue «Señor, en mi corazón»" ${ }^{68}$.

Estas leyendas sitúan a estas imágenes dentro de una larga tradición católica de esculturas hierofánticas que milagrosamente cobraban vida. En España estas historias fueron más predominantes desde el siglo XVI y se centraban en crucifijos e imágenes de la Pasión, el periodo y eventos que precisamente se recreaba en Semana Santa ${ }^{69}$. Estas asombrosas narrativas hacían hincapié en la aparente verosimilitud de las imágenes, como si su parecido hubiese sido verificado por Cristo mismo. Estas leyendas, transmitidas a través de la tradición oral, formaban parte de la memoria de la ciudad, lo cual no solo hace referencia a una especie de pensamiento mágico típico del folklore urbano español sino también muestra que este pensamiento depende de una idea de verdad real en lugar de verdad histórica. Tal y como el historiador del arte local afirmó, estas eran «[b] ellas leyendas que muchas veces proyectan más luz que cien documentos» ${ }^{70}$.

\footnotetext{
65 Besançon (2000): 165-168.

66 Walker Bynum (2011): 58; Bray et al. (2009): 15-44, 73-90.

67 DR 22 April 1943.

68 Agapito y Revilla (1913).

69 Christian (1989): 181-208; (2012): 45-96

70 García Chico (1952): 13.
} 
Las historias también hacían hincapié en la asombrosa corporalidad de las imágenes del barroco y en la genialidad de sus creadores. Sin embargo, tal y como señala Walker Bynum, esta misma habilidad mimética — tan característica del arte renacentista- a la vez pone el foco de atención en el artificio. Dado su excepcional realismo, y a pesar de la leyenda según la cual la imagen cobró vida, el Cristo de Juni todavía estaba hecho de madera. Aunque una vez que se convirtió en una imagen para las procesiones en 1942 — sustituyendo al tradicional Cristo de los Carboneros que resultó tener carcoma - la idea de artificio, o ilusión, se acentuó aún más. La tradición de las procesiones animaba a las propias imágenes y, en teoría, a su «espíritu», es decir, a la verdad emocional, histórica y religiosa subyacente. El arte era, por tanto, un vehículo para el espíritu - la esencia - del pasado. Tal y como el escritor, poeta y editor de El Diario Regional, Francisco Javier Martín Abril, señaló en 1941: «Nuestros grandes artistas... creaban arte más, al mismo tiempo, hacían oración... Lo castizo, aquí, deja paso a lo universal, es decir a lo auténticamente religioso ${ }^{71}$. Y no solo se limitaba a estos artistas. Cuando sus imágenes salían en procesión por las calles se creaba un tableau vivant gracias a la participación de los vallisoletanos, creando un palimpsesto que encapsulaba la historia y la memoria de todo lo que había pasado antes.

La Semana Santa era, por tanto, la puesta en escena del arte barroco para poder acceder a una tradición viva. En 1942 cuando la imagen de Jesús Nazareno se volvió a colocar en la recién restaurada Iglesia Penitencial de Jesús, al lado de la Plaza Mayor, «las graves cofradías» iban por las calles «como aquellas penitenciales del s.XVII, dando escolta a aquel mismo paso antiguo del Nazareno Camino del Calvario» al son de «los lentos y viejos redobles de tambor de la noche estrellada de todos los tiempos $»^{72}$. La ilusión denotaba atemporalidad; la tradición viva de la Semana Santa era llevada a cabo a través de las imágenes, que a su vez parecían cobrar vida en esta reconstrucción del pasado. La guía de Semana Santa de 1947 negaba explícitamente el tiempo histórico como lineal: las imágenes procesionales del barroco español comprimían y encapsulaban la historia, sintetizando la Edad Media y el Renacimiento, y omitiendo por completo la Reforma, la Ilustración y la Revolución Industrial subsiguientes ${ }^{73}$.

El énfasis en el arte situó al Museo Nacional de Escultura en el centro de la recuperación de la Semana Santa de Valladolid. En términos prácticos, esto fue en parte un ejercicio de publicidad ya que, aunque el museo ya había

71 «En el umbral de la Semana Santa», $D R 4$ de abril de 1941.

72 DR 25 de febrero de 1942.

73 Junta Pro-fomento de la Semana Santa (1947): 42-433. 
recibido el estatus y título de colección nacional por Fernando de los Ríos en 1933, había comenzado siendo una institución provincial ${ }^{74}$. Su sorprendentemente excelente colección de escultura policromada fue el resultado de la desamortización del siglo xix y reflejaba la riqueza y estatus de los conventos de la provincia. Era, por tanto, una colección específica importante que reflejaba una tradición escultural particular — quizás incluso un momento particular- más que al estado de las artes plásticas en España de manera más generalizada. Pero la Segunda República — y sobre todo la figura clave de Ricardo de Orueta, Director General de Bellas Artes desde 1931 hasta 1933—también consideraba al arte barroco religioso como una expresión cultural única del carácter español: «una producción original, españolísima, comparable a nuestra pintura castiza y a nuestro teatro: artes arraigadas hondamente en el alma del pueblo» ${ }^{75}$.

En cambio, después de la Guerra Civil la colección del Museo se reinterpretó bajo una manera de entender el arte muy sacralizada que difería de la representación secular y nacionalista durante la República. Aunque, había una clara interpretación de las imágenes religiosas policromadas como «las creaciones más singulares del genio de España», ahora estaba particularmente asociado a una profunda sensibilidad religiosa y propósito, "la concepción espiritual de la vida espańola» ${ }^{76}$. Los imagineros habían trabajado "con una actitud mística de auténticos creyentes, pensando en despertar el dulce escalofrío de la fe en las gentes que constituyeron el verdadero público» ${ }^{77}$. La interacción entre la imagen y la audiencia daba vida a la imagen, y transportaba al vallisoletano del siglo xx al momento de su creación. En esencia, esto era el propósito del Barroco y, como con el caso de las procesiones, el Museo ofrecía un vehículo al pasado.

Mientras que "el museo muchas veces es una necrópolis» el Museo Nacional de Escultura «tiene vida». A pesar de las protestas de expertos y críticos, "partidarios de las lenguas muertas, el arte muerto", los pasos salieron a la calle, en lo que era una tradición viva más que un arte muerto ${ }^{78}$. El director del Museo, Francisco de Cossío — quien no tenía formación oficial en arte o historia del arte y a quien debía su nombramiento al patronato del político de la Restauración Santiago Alba - tenía una manera idiosincrásica, y muy

\footnotetext{
74 Pasos restaurados (2000): 5.

75 Pasos restaurados (2000): 8; sobre Orueta, ver Bolaños (2013) y Acción Cultural Española (2014): 38-77.

76 Barberán (1948): 13, 16.

77 DR 29 de marzo de 1942.

78 Junta Pro-fomento de la Semana Santa (1947): 43.
} 
sacralizada, de entender la colección ${ }^{79}$. La labor encomendada a Cossío era "hacer un museo vivo, activante y no pasivo». El museo no podía seguir existiendo como en el pasado; la victoria de la Cruzada significaba que "debe ser mucho más y, sobre todo, debe ser otra cosa». La Junta de Patronato - en la que estaban el arzobispo, el alcalde y el gobernador civil- acordó que el museo «no olvidará jamás lo que es la escultura religiosa». El arte era un medio religioso, el artista "un fiel más». El propósito de las imágenes era «recibir culto». La labor del museo era, por tanto, asegurar que las imágenes fueran contempladas con respeto y decoro, y con suerte, el «solemne aislamiento» llevaría a «la íntima plegaria mental $»^{80}$.

La colección original del Museo solo constaba de imágenes que no eran objeto de culto; las que sí recibían culto permanecían dentro de las iglesias. Como institución, ganó su estatus de colección nacional en la Segunda República y adquirió su colección como resultado de la secularización producida por la desamortización, que debilitó el poder económico de la Iglesia y cambió la naturaleza del estado confesional. Su recodificación después de la Guerra Civil fue altamente política, restituyendo tanto los impulsos secularizadores de la Segunda República y las (de)codificaciones anticlericales de la Guerra Civil. Aunque Valladolid no había experimentado el iconoclasmo de la Guerra Civil, Cossío interpretó la desamortización en términos sorprendentemente similares, escribiendo cómo las estatuas habían llegado al almacén "como los heridos de una batalla, cojos, mancos, descalabrados, muertos... Entonces, como ahora, el arte español recibió un golpe terrible» ${ }^{81}$. La razón era, como durante la Cruzada, «una contrarreligosidad fanática».

La reinterpretación de la desamortización de Cossío incluía a Valladolid dentro de la España amenazada por la revolución anticlerical, en este caso condonada por miembros de la Academia de Bellas Artes ${ }^{82}$. Al final de la Guerra Civil todo el mundo había oído acerca de la reconversión de las iglesias en la zona republicana como almacenes, teatros y prisiones ${ }^{83}$. En estos casos el acto de iconoclasia radicaba precisamente en su recodificación como edificios seculares; su profanación vino después. Del mismo modo, todo el mundo sabía que la Segunda República había "prohibido» las procesiones de Semana Santa en un intento por secularizar el espacio público. Ahora - en un intento claro de restitución por el sacrilegio tanto de la República en los ańos treinta

\footnotetext{
79 Cossío (1959): 64-65, 120.

80 «Hacia un museo vivo», "Actas», 4 de mayo de 1940.

81 Cossío (1939): 76-77.

82 Cossío (1959): 120.

83 Thomas (2013): 131-136.
} 
como de Mendizábal en la década de los treinta del siglo XIX — los pasos procesionales del Museo estaban siendo cuidados. Estos se mostrarían en «una sala enorme», escasamente iluminados con «una organización decorosa y grave», y elevados por encima de los visitantes, quienes podrían caminar alrededor de los mismos como si estuviesen en la calle ${ }^{84}$. El espacio secularizado del museo nacional se había convertido, a todos los efectos, en tierra santa.

\section{A TRAVÉS DEL ESPACIO}

Las procesiones, tal y como fueron «recuperadas» en los años cuarenta, eran puestas en escena deliberadas de la eterna España católica. Las procesiones de Semana Santa como actos de liturgia se convirtieron en un vehículo para la inmanencia en un sentido temporal. Pero también tenían una función espacial y sacralizante, ya que transformaban las calles de la ciudad en un "templo viviente». Este alarde de "la eterna Espańa» fue reproducido mecánicamente. La Semana Santa se convirtió en un cliché del NO-DO, que aparecía editado como un compendio o "mosaico» de tradiciones religiosas. Se presentaba como atemporal tanto en su simbolismo como por su repetición anual, y era un punto de referencia familiar para la "Cruzada» franquista. Las celebraciones eran tanto universales como locales, y representaban tanto la redención del mundo como el carácter regional de la España eterna, sin contaminar por la secularidad. La Castilla «austera» contrastaba con la Andalucía "pasional»: «Andalucía, la desgarrada, grita lo que sufre calladamente Castilla» ${ }^{85}$.

Precisamente estos tropos se vieron reflejados en el guión de una película encargada por la ciudad de Valladolid en 1941, dos años antes del primer NO-DO. La ciudad todavía estaba bajo control militar y la película finalizaba con «un desfile de organizaciones juveniles o militares», el escudo de la ciudad y una referencia al Glorioso Movimiento. Comenzaba con las llanuras de Castilla y continuaba con tomas del casco antiguo de la ciudad, con sus iglesias históricas y jóvenes mujeres con mantillas. El paisaje, la historia, el carácter local y la fe religiosa convergían en la celebración anual de la Semana Santa. La voz en off hablaba de cómo «[E]n este estuche de viejos monumentos, la piedad de Castilla ha conservado la austera joya de sus procesiones pasionales»

Actas: 7.

85 Tranche y Sánchez-Biosca (2000): 529-531; 567-571; http://www.rtve.es/filmoteca/ no-do/, No 68 y No 171; para correspondencia con el NO-DO, AMV, caja 468-9, $\operatorname{docs} 27,30$. 
y comparaba la procesión de Viernes Santo con «un río piadoso sobre la ciudad, plana del pueblo emocionado. ... La religión es aquí, como esta raza austera y noble, callada y sentida hondamente». La austeridad se dejaba traslucir por el respetuoso silencio en las calles, y la emoción quedaba reservada para las imágenes, especialmente "la Virgen de las Angustias que labrara Juni, quintaesenciando el humano dolor ${ }^{86}$.

Estos temas e imágenes, tan estereotipados como los del NO-DO, se reflejaban en incontables representaciones - escritas, gráficas y fotográficasde la Semana Santa en la ciudad. Además en esta ocasión había un claro propósito comercial detrás de la retórica. La película había sido encargada para publicitar la Semana Santa pero el producto final «no responde ni pone de manifiesto la suntuosidad y grandeza de nuestra Semana Santa vallisoletana». La película fue rechazada por no ser «útil para la propaganda», una decisión tomada después de haber sido mostrada por segunda vez a las autoridades civiles, militares y eclesiásticas, cofradías, periodistas y empresarios ${ }^{87}$. La reacción fue unánime, y probablemente fuese un reflejo de las dificultades técnicas y de la baja calidad del producto final. El guión no tenía ningún problema y la película había sido aprobada por los censores y había obtenido todos los permisos eclesiásticos ${ }^{88}$. Aunque este desafortunado estado de cosas podía también estar reflejando el hecho de que en 1941 los planes de la ciudad para la Semana Santa no se adecuaban con la realidad.

La Semana Santa en toda España transformaba las calles de las ciudades en calvarios. La recreación penitencial de la Pasión de Cristo restituía tanto los pecados del mundo como los pecados de España de manera espacial y tempo$\mathrm{ral}^{89}$. Las liturgias de Semana Santa eran performativas, y el hecho de llevarlas a cabo en las calles de la ciudad creaba una visión de la España eterna que existía en el espacio urbano. Esto era significativo ya que, a pesar de las alabanzas del régimen a las virtudes del mundo rural, el Nuevo Estado suponía el fin para la mayor parte de la Espańa rural. La aparición de oportunidades para algunos - y la alarmante pobreza de muchos - hizo que cada vez más gente migrase a la ciudad. Las ciudades de la Espańa de Franco necesitaban su propia mitología, algo que la Semana Santa podía ofrecer. Las películas y noticias muestran cómo las ciudades se consideraban emblemas del paisaje — quizás

86 «Realización de una película de la Semana Santa de Valladolid por la casa "España Actualidades" 1941» AMV Caja 489-53, guiones: documentos 2 y 9.

87 Carta del alcalde, 14 de julio de 1941 AMV caja 489-53, doc. 39.

88 Correspondencia, AMV caja 489-53, docs. 23, 29, 38; la productora de la película se quejó de la escasa iluminación y de la imposibilidad de algunas tomas.

89 Hernández Burgos (2015): 170-173; Richards (2005): 211-220. 
particularmente las llanuras de Castilla - pero las liturgias estaban firmemente ancladas a paisajes urbanos históricos.

Este sentimiento de pertenencia fue clave tanto en la consideración de la Semana Santa como una tradición viva como en su éxito. De la misma manera en la que la potencia emotiva de las imágenes radicaba en su relación con la audiencia, los ciudadanos definían la «ciudad» en igual manera por sus calles y edificios históricos. La puesta en escena de la Semana Santa transformaba la ciudad a través de la participación de la gente, tanto como cofrades como espectadores ${ }^{90}$. Esto siempre se consideró como una manifestación del sentimiento religioso, una externalización de la piedad. «[E]s la expresión de fervor general que convierte las calles en templo... Sobre el tesoro artístico... hemos sabido poner un ambiente de austeridad fervoroso, de silencio manso, que invita a la oración ${ }^{91}$. También contrastaba con otras ciudades - Cossío, por ejemplo, recordaba salir de misa en París el día de Viernes Santo para encontrarse con que «nos está esperando la ciudad con sus ruidos y sus locuras»con Valladolid durante otros momentos del año ${ }^{92}$. Imágenes de la ciudad «austera» castellana con sus calles abarrotadas transformadas en un templo en silencio se convirtieron en un leit motiv de la Semana Santa de Valladolid. Fernando Ferreiro Rodríguez, alcalde de Valladolid desde 1943 — cuando la ciudad dejó de estar bajo control militar- hasta 1949, describió esto en los siguientes términos: "convertido en templo y museo, piedad y arte unidos en el silencio", demostrando la manera en la que en Castilla, según Cossío, «podréis encontrar... la emoción religiosa más fuerte y penetrante que puede ofreceros España» ${ }^{93}$.

No obstante, a pesar de este espíritu "eterno», la transformación de la ciudad durante Semana Santa era temporal y performativa, y muchos participantes eran conscientes de esto. Cuando el por entonces disidente falangista Dionisio Ridruejo dio el pregón en 1952 se refirió a cómo la "natura española» reencarnada en las imágenes del Barroco transformaban a la ciudad en un «sermón viviente», es decir, en una experiencia didáctica transitoria ${ }^{94}$. La ciudad estaba considerada como un "teatro» o un «museo viviente», símiles que reflejaban la manera en la que la Semana Santa estaba considerada como una puesta en escena deliberada de piedad al igual que de su manifestación. En términos prácticos la ciudad se recreaba como un escenario de teatro con

\footnotetext{
90 Sobre la Semana Santa como teatro, ver Gavilán Domínguez (2005).

$91 \quad D R 13$ de abril de 1943.

92 Cossío (1959): 288.

93 "Conferencia de Francisco de Cossío en Madrid», NC 29 de marzo de 1942.

94 Lipari (2014): 187.
} 


\section{IMAGEN 1. La procesión del azotamiento del señor en Valladolid, 1954}

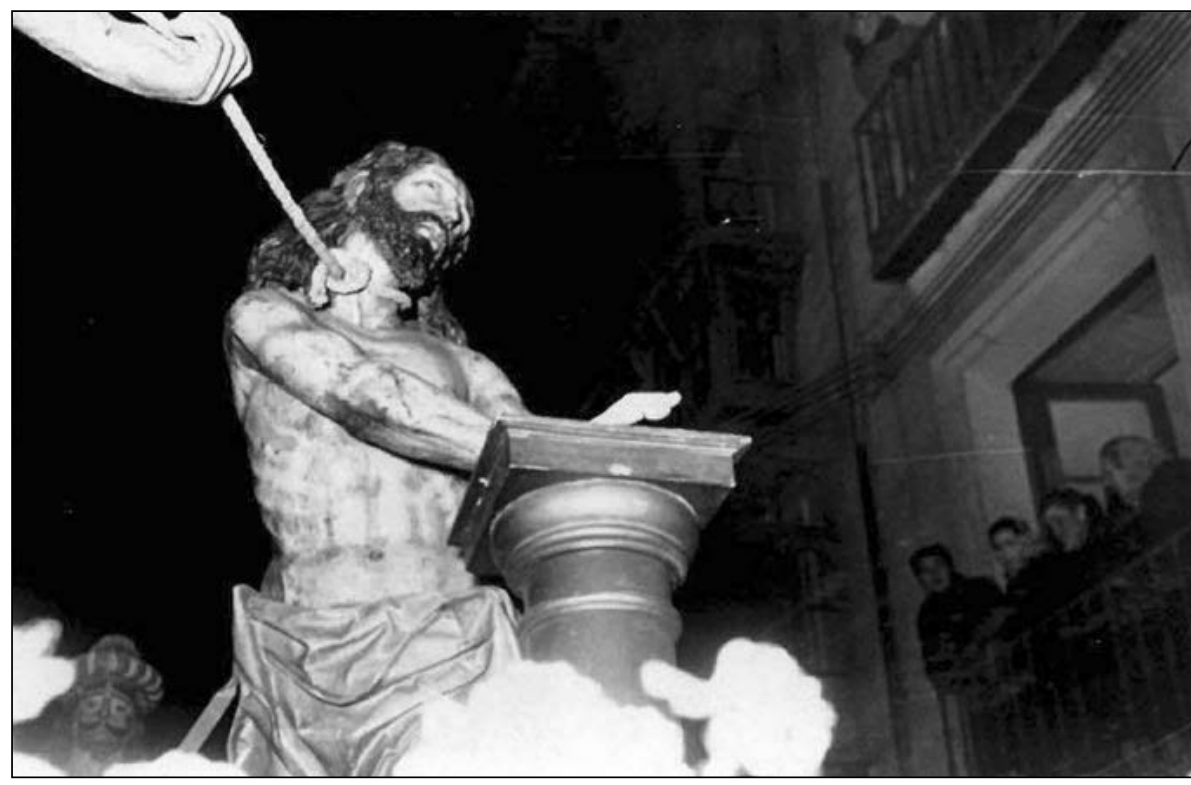

Fuente: Archivo Municipal de Valladolid. Signatura: AUX 00317-145.

cruces erigidas para el Vía Crucis del miércoles y reflectores y altavoces colocados donde fuera posible ${ }^{95}$. La iluminación era clave: el alumbrado público se apagaba durante las procesiones nocturnas para que la oscuridad y el silencio definiesen la ciudad y acentuasen el sonido y espectáculo de la procesión de las sagradas imágenes.

Muchas de estas medidas requerían mediación municipal. No era solo cuestión de restringir el tráfico o prevenir aglomeraciones de gente, aunque esto también era esencial. Al menos desde los años treinta los bandos del Ayuntamiento en Semana Santa también regulaban conductas e insistían en "la compostura y respecto debidos» y se aplicaban multas a todos aquellos que perturbasen los actos litúrgicos u ofendiesen «los sentimientos de los concurrentes a ellos» ${ }^{96}$. Estas disposiciones siempre habían sido controladas. Sin embargo, desde 1945 los bandos se tomaban en cuenta «escrupulosamente» y

95 DR 23 de marzo de 1940, 9 de abril de 1941, 13 de marzo de 1942; en 1941, a la gente también se le pidió que sacasen radios a los balcones y sintonizasen Radio Valladolid.

96 «Bandos de Semana Santa», 1930-1, 1937, 1939, 1941-2, 1944, AMV, legajos 229-22, 487-41, 487-51, 488-5, 488-19, 488-30, 488-36, 488-48. 
los «hechos que constituyan delito contra la Religión Católica» se procesaban bajo el Nuevo Código Penal ${ }^{97}$. Dos años después el bando especificaba que los bandos debían de ser respetados por "todo el vecindario" y serían controlados «con la mayor exactitud». En 1948 el mandato en el que se ordenaba a los ciudadanos y ciudadanas que debían guardar "toda la compostura» se amplió indicando que debían abstenerse «del menor desorden o cualquier otro género de profanación ${ }^{98}$.

Algunos de estos cambios reflejaban el fin de la ley marcial. Habría menos necesidad de definir el comportamiento correcto mientras la ciudad estuviese bajo total control militar. Obviamente, la prohibición de disparar armas de fuego o lanzar petardos el Domingo de Resurrección no sobrevivió a la Guerra Civil y pocos habrían desobedecido las normas sociales y religiosas durante los ańos de máxima represión. La ciudad de Valladolid había sido controlada por los rebeldes en cuestión de horas - y la provincia en menos de una semana- pero las detenciones, ejecuciones y desapariciones empezaron inmediatamente y se cobraron más de dos mil vidas y sobrepasaron los tres mil encarcelados ${ }^{99}$. Sin embargo, incluso cuando disminuyó la violenta represión y cambiaron las condiciones, la referencia a la "profanación» sugiere un proceso de sacralización más amplio: la aceptación de que durante la Semana Santa la ciudad se había convertido, en efecto, en una iglesia.

Este mensaje no solo estaba reforzado por el uso de referencias metafóricas de la ciudad como templo sino también por recordatorios detallados sobre el tipo de comportamiento esperado por todos aquellos que fuesen a ver las procesiones o participasen en ellas. Debían comportarse en la calle como si estuvieran en la iglesia. Esta recreación de la ciudad como espacio sagrado que «exige mucho a los habitantes de Valladolid» mostraba el carácter de la ciudad que «se hace templo para que el rito tenga lugar a cielo raso (sic)». Aquí «no cabe la nota más o menos colorista sino el silencio impresionante de una multitud que reza $»^{100}$. Este contraste con el sur folclórico hacía de nuevo referencia a la Castilla «austera»; durante la Semana Santa se mostraba el carácter de la ciudad, el comportamiento de sus ciudadanos reglamentado por los códigos gestuales más apropriados en tierra santa. En esta ciudad convertida en templo, el silencio era fundamental. A medida que el paso se acercaba todo el mundo debía agachar su cabeza y hacer la señal de la cruz, y por supuesto, rezar. Todos debían evitar el escándalo, «el espectáculo irrelevante», por

\footnotetext{
Bando de 1945, AMV legajo 229-31.

8 Bandos de 1947 y 1948, AMV legajos 255-13, 255-38.

99 Martín Jiménez (2000); Palomares Ibañez (2001); Preston (2012): 188-193, 669.

100 «Comienza la Semana Santa», DR, 29 de marzo de 1942.
} 
ejemplo, de hacer la señal de la cruz torpemente con un gesto «que ni es la cruz con que se santigua ni cosa que se le parezca» o "que alzan el brazo ante las sagradas imágenes, dando muestra de su ignorancia y también de su buena fe» ${ }^{101}$.

Este poderoso refuerzo del decoro cristiano muestra que no era simplemente la exteriorización de una fe religiosa que creaba «el respeto, admiración y recogido silencio con que los fieles presencian el paso del cortejo procesional $»^{102}$. Como dejaban claro los bandos, este código sobre los gestos era de obligado cumplimiento por la ley y estaba reforzado por medidas coercitivas que incluían la continua vigilancia del resto de participantes. La referencia a los saludos fascistas muestra que - como era de esperar dada la asociación de Falange con Valladolid- podían verse durante la Semana Santa de 1943, aunque nunca apareciesen en fotos en la prensa. Por supuesto, a diferencia de gestos irrespetuosos, el saludo romano no podía prohibirse. Sin embargo, la Iglesia cada vez se sentía más incómoda con símbolos falangistas en enclaves eclesiásticos y la extensión temporal del espacio sagrado a toda la ciudad daba la oportunidad para ejercer su autoridad sobre las costumbres públicas.

El decoro siempre fue motivo de preocupación durante la Semana Santa, especialmente en el caso de las mujeres ya que tanto su vestimenta como su comportamiento eran considerados como símbolos de la salud moral de la sociedad. De hecho, la exigencia de modestia excedía la devoción religiosa. La procesión de la Soledad era la única que permitía a mujeres penitentes, ya que era no mixta, y se les tenía "terminantemente" prohibido ir sin medias-'negras y ....densas'-incluso si iban descalzas ${ }^{103}$. La guía oficial en 1940 pedía "[a]unque sea 'innecesario', dada la cultura de esta capital» que "los caballeros» evitasen el área que circundaba la Iglesia Penitencial de las Angustias «a fin de no distraer a las señoras» que hacían visitas devocionales a la Virgen de Juni ${ }^{104}$. Esta expresión repetía tropos conocidos. Dado el carácter de la ciudad y la educación de sus ciudadanos, no cabía duda de la necesidad de evitar que las mujeres fueran molestadas durante sus devociones. Pero, sin embargo, esta orden había sido dictada para recordar las reglas de comportamiento a los hombres en una "noche de tanto recogimiento y respeto".

El decoro de Semana Santa no era solo un asunto religioso. La imagen fotográfica más famosa de la Semana Santa en los años cuarenta es

101 «Vida Cristiana», DR 4 de abril de 1943.

102 NC 24 de abril de 1943.

103 Notificación del Vicario-General, P. José Zurita, DR 31 de marzo de 1942.

104 Guía (1940): 37. 


\section{Imagen 2. Sermón de las 7 Palabras en Valladolid, 1954}

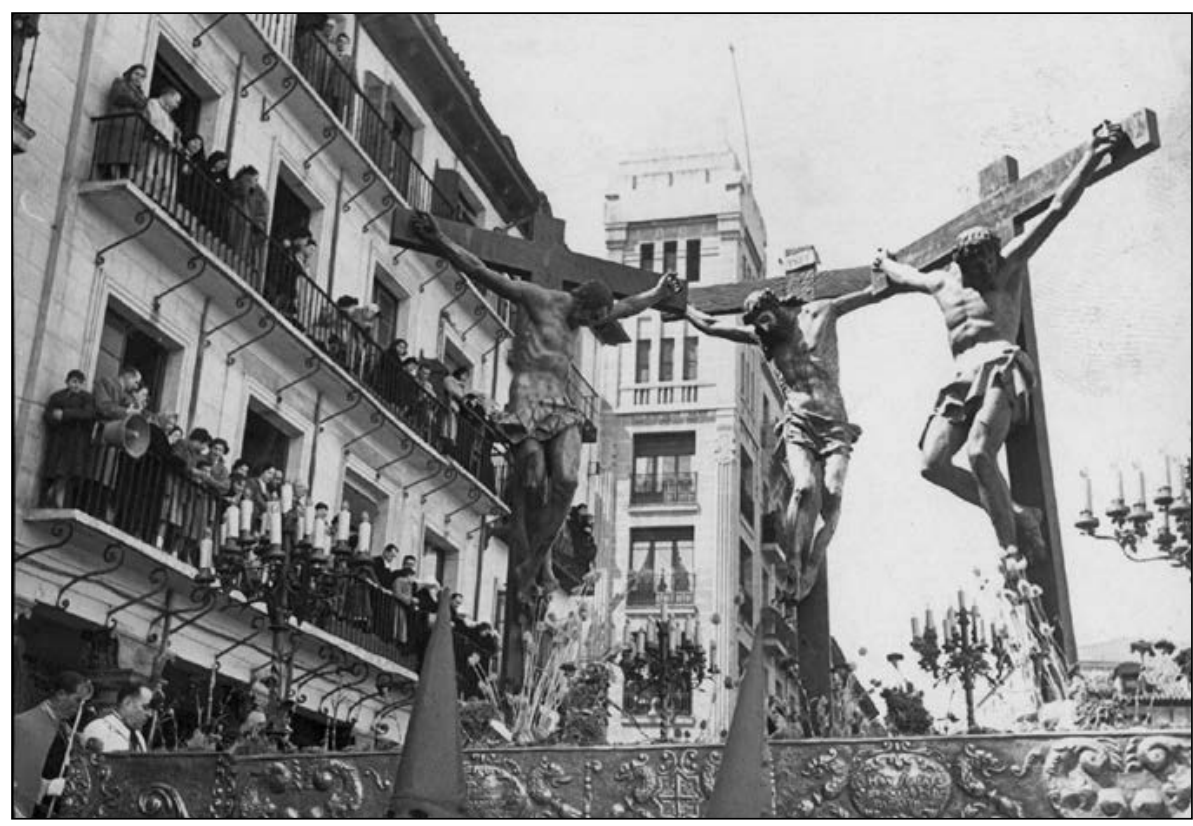

Fuente: Archivo Municipal de Valladolid. Signatura: 00267-037.

probablemente la de las mujeres jóvenes con mantillas, sujetando rosarios y misales y yendo a la iglesia el día de Jueves Santo, antes de la reserva del Santísimo Sacramento en Viernes Santo, cuando los sagrarios estaban vacíos. Más que la fe religiosa, su vestimenta y comportamiento representaba la tradición española, el decoro femenino y — con sus guantes, joyas y trajes a medidaetiqueta burguesa. El estado de ánimo de la ciudad cambió. En contraposición a la solemnidad del templo al aire libre de Viernes Santo o durante del Vía Crucis del miércoles «[1]a calle se convierte el Jueves Santo en gran pasillo de casa familiar ${ }^{105}$. Para 1945 las calles ya aparecían abarrotadas de gente que iba «ininterrumpidamente» a las iglesias, incluyendo a los del «Ayuntamiento, en corporación» a las 12:30 y justo después a «las tropas de la guarnición» ${ }^{106}$.

Esta visita formal cívica por las autoridades municipales había sido aprobada en 1940, aparentemente «reestableciendo una antigua costumbre» ${ }^{107}$.

105 Francisco Javier Martín Abril, «La paz de Jueves Santo», DR 6 de abril de 1944.

106 NC 31 de marzo de 1945.

107 DR 21 de marzo de 1940. 
Sean cuales sean sus orígenes, el papel ceremonial reflejaba el trabajo práctico y esencial llevado a cabo por el Ayuntamiento que aseguraba que la Semana Santa fuese un éxito. También deja entrever algo sobre la vida política municipal en los años cuarenta y, en años posteriores durante la dictadura. La política bajo Franco se circunscribía a una esfera de acción muy limitada, a aquella estrictamente relacionada con las personas directamente involucradas en ella. Sin embargo, los funcionarios municipales necesitaban hacer algo, y tenían que ser vistos haciendo algo. Las conmemoraciones, ceremonias y liturgias tenían un propósito, y contribuían en gran manera al extraordinario ritualismo del régimen. También dejaban ver quién estaba en el poder y quién no, mostrando una vez más el riguroso orden jerárquico de una ciudad supuestamente «reintegrada» en una armonía más amplia.

La expresión más clara de este orden jerárquico de la ciudad era lo que se convertiría en la liturgia de la Semana Santa vallisoletana más exitosa y característica, el Sermón de las Siete Palabras. Gandásegui lo introdujo en 1932 siguiendo un modelo latinoamericano y fue en sus orígenes otra devoción de Semana Santa predicada en la catedral. Sin embargo, después de la Guerra Civil el sermón se transformó en un evento decisivo. En contraposición con las procesiones, que se centraban en el movimiento y la imagen en lugar de la palabra y el texto, y en las que las cofradías laicas desempeñaban un papel crucial, el sermón era una exposición de la palabra de Dios por un sacerdote. Su propósito era de catequismo, es decir, instruir a la gente en la doctrina cristiana, y su mensaje era autoritario. El predicador, elevado sobre la congregación, hablaba con la voz de Roma. El sermón añadía un nuevo énfasis, en la catequesis, la predicación y el texto, que se reforzó después de 1948 cuando se añadió a la ceremonia hablada un pregón que fue normalmente pronunciado por un seglar. Ahora, el significado de Semana Santa derivaba en parte de la intersección entre palabra e imagen ${ }^{108}$.

Esta era claramente la intención después de que el Sermón de las Siete Palabras se hubiera trasladado a la Plaza Mayor en 1943, un momento de éxito clave. Los confines de la plaza eran lo suficientemente grandes para acomodar al púlpito y los pasos, así que los fieles podían ver las «últimas palabras» desde la cruz y oír las meditaciones. Las palabras del clero guiaban la mirada del público, aunque no había manera de comprobar que todo el mundo estuviera escuchando. El efecto teatral era impactante, incluso cuando solo hubo un único paso, el del Cristo crucificado entre dos ladrones, como en 1943. El paso se llevaba a la plaza donde sería flanqueado por dos filas de dignatarios civiles, militares y eclesiásticos al igual que representantes de las cofradías

108 Lipari (2014). 
jerárquicamente organizados. Aquellos con asientos se sentaban por orden, y a menudo se distinguían por su vestimenta, mientras que el público permanecía de pie al fondo o miraba desde los balcones. Las fuerzas vivas de la España urbana permanecían reunidas, con una disposición disciplinada y jerárquica, para escuchar la palabra de Dios.

El Sermón de las Siete Palabras era una tradición completamente inventada no solo en Valladolid sino también en el resto de España. No obstante, se hacía alusión desde el principio a su existencia «rememorando una antigua costumbre de siglos pasados» ${ }^{109}$. Quizás como su base histórica —básicamente la existencia de un sermón al aire libre- era tan poco sólida, se situaba en el presente histórico, es decir, el momento de victoria.

Castilla la austera... vuelve a recordar... su grandeza del siglo de oro. Y como en épocas pasadas, siguiendo una tradición interrumpida por algunas centurias, torna Valladolid a colocar la Cátedra Sagrada en la Plaza Mayor para enardecer el corazón castellano al oír aquellas palabras que un Hombre-Dios exclamara al expirar en una Cruz. [...] Después de nuestra Cruzada, vuelve Valladolid, capital que fue un buen día del Imperio Español, a renovar sus tradiciones de abolengo religioso. Mañana...el pueblo vallisoletano... acudirá en masa a la Plaza Mayor...a meditar los grandes padecimientos de Cristo y el amor inmenso que Él tuvo a los pecadores cuando abrió sus brazos divinos en la Cruz ${ }^{110}$.

Esta reconstrucción intencionada de un tiempo que nunca tuvo lugar y de un evento que nunca existió hacía posible una muestra penitencial altamente teatral, y era particularmente efectivo dado el enclave. Los confines de la Plaza Mayor, delimitados por cada lado y vigilados desde cada ángulo, proporcionaban el clima adecuado para crear un microcosmos de la ciudad "austera» y fiel $^{111}$. La gente de Valladolid se sentaba o permanecía de pie y estaba colocada en filas ordenadas para escuchar la palabra de Dios, que también era, por supuesto, la palabra de las autoridades nacional-católicas. Todos estaban expuestos al público y sujetos a comunes mecanismos de vigilancia según una disciplina simbólica y expiatoria, un componente clave del Nacionalcatolicismo. Aunque hubo alguna mención puntual a la violencia anticlerical de la Guerra Civil — siempre identificada con la República desde sus inicios — la restauración que la Semana Santa en Valladolid ofrecía estaba basada en el la idea de

109 DR 24 de abril de 1943.

110 P. V. Bayón, «El Sermón de las 7 Palabras», DR, 22 de abril de 1943.

111 Semana Santa Valladolid, fotografías 5-7. 
desaparición ${ }^{112}$. Devolviendo a la ciudad a una esencia histórica, como si la República nunca hubiera existido.

Este era un tema recurrente para dos cronistas de la ciudad muy diferentes: Cossío y Martín Abril. A pesar de sus diferenciadas posiciones políticas - Martín Abril había sido cedista y miembro de la ACNP y había adoptado una posición algo más disidente en los años cincuenta, mientras que el arraigado conservadurismo de Cossío se había visto profundamente afectado por la muerte de un hijo falangista en el frente- ambos adoptaron un tono lírico en los artículos que publicaron, especialmente en aquellos en los que trataban costumbres locales y del día a día ${ }^{113}$. Este hecho en sí mismo contribuyó en gran manera a «naturalizar» las tradiciones inventadas de la postguerra en Valladolid, sobre las cuales ambos estaban convencidos que capturaban la esencia de la elegante ciudad castellana. Según Martín Abril, durante la Semana Santa «el concepto de la tradición se hace tangible, hasta el punto de sentirla vivir entre nosotros como un personaje más» ${ }^{114}$. Cossió también se hizo eco en 1948 de esta idea de hacerse manifiesto, cuando fue elegido para dar el primer pregón de Semana Santa ${ }^{115}$. Se deleitaba del espectáculo en la Plaza Mayor, cómo se caracterizaba por «un silencio que se hace tangible, que se respira y se toca» y que estaba acompańado por «el orden, el orden sometido a una disciplina religiosa y a un ritmo solemne». Este espectáculo austero, disciplinado y jerárquico - la muestra perfecta del orden social tomista - era el trabajo tanto de Dios como de la historia ${ }^{116}$. Ya que «[1]a Historia no está solo en los archivos y en los libros, la llevan dentro de si los hombres. La Historia es, de una parte, el peso del pasado, y, de otra, la sangre. Yo estoy seguro de que las nuevas cofradias, aún más que vivir, revivir, sienten sobre si la responsabilidad del pasado, e interpretan un papel histórico de un modo perfecto ${ }^{117}$.

A pesar de la retórica y la emoción transmitida por Martín Abril y Cossío, fue el reconocimiento a todos aquellos que habían participado en la Semana Santa, y en particular en el Sermón de las Siete Palabras, el que hizo que fuese todo un éxito. Este sentido de «representación» proporcionaba plasticidad al evento y permitía sacarle el máximo rendimiento a su éxito. Se

112 Por ejemplo, el DR 22 de abril de 1943 recordaba cómo Gandásegui había sido testigo de "la Religión sacrosanta de nuestros mayores atacada y brutalmente escarnecida públicamente».

113 Pérez López (1994): 156-8; Cossío (1948).

114 «La paz del Jueves Santo» DR 6 de abril de 1944.

115 Lipari (2014): 80ff; Martín Abril dio el segundo al ańo siguiente.

116 Ver Vincent (2007).

117 Cossío (1948): 8-9. 
añadieron ornamentos adicionales, especialmente la incorporación de pregoneros montados con capirotes y capas quienes anunciaban el sermón por la ciudad, sin cortapisas dada la libertad de no tener que acatarse a ningún pasado histórico definido ${ }^{118}$. En contraposición con el medievalismo altamente artificial del Milenario de Castilla del año anterior, este adorno barroco adicional no tenía tintes descabellados y fue rápidamente naturalizado como parte de una escena simultáneamente atemporal y que recreaba el Siglo de Oro español.

IMAGEN 3. Caballero dando el pregón del Sermón de las 7 Palabras en Valladolid, 1954

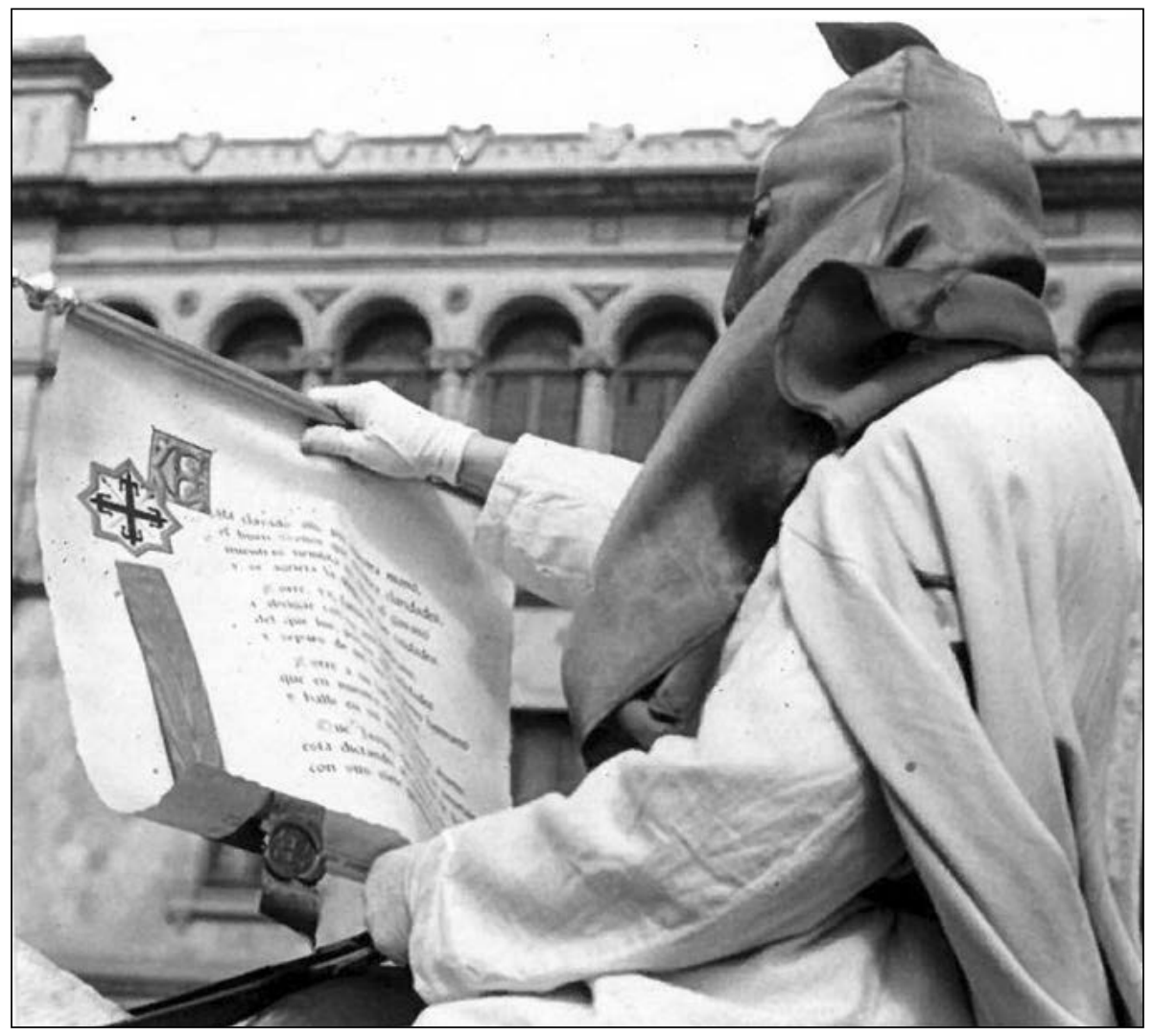

Fuente: Archivo Municipal de Valladolid. Signatura: F00561-005.

$118 \quad N C 8$ de abril de 1944. 
El éxito del Sermón de las Siete Palabras es indudable y fue motivo de noticia en el noticiario del NO-DO en 1944 y posteriormente en $1946^{119}$. Aunque no fue televisado hasta 1963, en 1939 fue emitido en la radio nacional. Una parroquia en Madrid incluso sugirió comprar una radio para poder escucharlo, junto con el discurso de Navidad del Papa ${ }^{120}$. En un periodo de tiempo increíblemente corto este nuevo ritual eclesiástico y cívico había sido asimilado como un evento con afianzadas raíces históricas, que demostraban la naturaleza nacional-católica, no solo en Valladolid sino también en Castilla y, por extensión, en España. Esto significó el apoyo y publicidad por parte de numerosos cuerpos gubernamentales y a su vez significó que podría salir adelante y florecer incluso dentro del duro contexto de la postguerra española. Pero su duradero éxito - que incluso sobrevivió al franquismo que lo había creado- se debió a un atractivo universal que tocaba en referencias históricas, artísticas y populares más amplias de lo que la Semana Santa pudiera reunir. La Semana Santa era quizás una tradición única dentro del contexto de las tradiciones inventadas por el Franquismo ya que, a pesar de sus características penitenciales y expiatorias, capturaba la imaginación popular.

\section{CONCLUSIÓN}

La Semana Santa de Valladolid desde 1939 se había creado como una muestra del nacionalcatolicismo español. En toda la geografía española la Semana Santa facilitaba la recreación imaginativa del pasado barroco, en un modo específicamente penitencial, de una manera apropiada en momento inmediatamente posterior a la Guerra Civil. La fe católica del pasado imperial se recreó como el «corazón» del nacionalcatolicismo español, es decir, la Hispanidad. Las miniadas, y en ocasiones iluminadas, procesiones, arrojaban luz sobre el pasado y el futuro - el futuro del franquismo en España, y a través del drama de la redención sobre el futuro del mundo. En su formalidad, la puesta en escena de la Semana Santa era típicamente característica del nacionalcatolicismo. El aparato represor del régimen no era solamente visible sino que se celebraba de una forma altamente ritual. Esto era una clara expresión del Nuevo Estado y del nacionalcatolicismo, y no únicamente otro ejemplo entre muchos de las devociones y matices del catolicismo barroco. El Barroco

119 N68 y N171.

120 Archivo Histórico Diocesano de Madrid, carta de un párroco de la comunidad, N. ${ }^{a}$ S. a de los Ángeles 3 de Diciembre de 1943, legajo 2585, carpetilla 7. 
era un vehículo cultural clave a la hora de entrelazar estos valores estéticos y políticos que estaban refundidos en un molde penitencial.

El Sermón de las Siete Palabras de Valladolid demostraba claramente la disciplina penitencial, un componente clave del nacionalcatolicismo y que se relacionaba con nociones catárquicas sobre la purificación y la violencia represiva de la postguerra. Las ceremonias inventadas de Semana Santa parecían ser a la vez históricas y atemporales pero, por supuesto, no eran así, incluso al tener sus cimientos en un legado histórico y en una excepcional y rica tradición artística gracias a una indiscutible conexión con el Barroco. Esto también permitió llevar más allá de la Cruzada de Franco a las asociaciones históricas —el sentido de profundidad temporal — y dotar de contexto incluso para aquellas personas que carecían de una profunda fe religiosa. La Semana Santa tenía connotaciones seculares, algo de sobra conocido por los organizadores, aunque para las personas creyentes era un drama trascendental y eterno que no solo precedía al estado Nacional-Católico sino que también perduraría en el tiempo. Pero para todo el mundo la Semana Santa era un evento anual, una serie de acciones repetidas que continuaban primavera tras primavera, y estaba arraigada en las vidas de individuos, familias y de la propia ciudad. Martín Abril capturó este significado cuando años más tarde escribió: «Pero los días andan, siguen andando... como sigue andando nuestro corazón» ${ }^{121}$.

El contraste entre Semana Santa y el limitado éxito de otros rituales, especialmente falangistas, era enorme. La durabilidad de la Semana Santa contrastaba con los ritos de victoria seculares, que pronto se vieron vacíos de contenido y se convirtieron en repeticiones de gestos y prácticas que iban gradualmente perdiendo su significado. En Valladolid, entonces, no vemos el proceso de convertir un rito popular en una ceremonia oficial ${ }^{122}$. En esta ciudad, la Semana Santa adquirió su aspecto actual, y su atractivo popular, sólo después de la Guerra Civil. Esto no quiere decir que los significados de la Semana Santa no cambiasen. De hecho, asumir un sentido de «atemporalidad» la separaba de la cruel e inmediata realidad de la victoria de Franco. Esta cualidad polisémica significaba que la Semana Santa podía reinventarse, aunque no fuese de manera drástica, al menos respecto a las interacciones entre los y las habitantes de la ciudad y las imágenes y rituales que admiraban. Ser espectadores - y estar sujetos a una respuesta emocional ante el sufrimiento de la virgen, a admiración por el arte o simplemente a un sentimiento de familiaridad- permitía diferentes interpretaciones y cambios de perspectiva, tanto a nivel colectivo como individual. Esto permitió que la Semana Santa retuviese y cambiase sus

121 Martín Abril (1969): 21.

122 Ver Rina Simón (2015a) en el caso de Cáceres. 
significados a lo largo de periodos de profundo cambio religioso en los años sesenta y de cambio político en los setenta, y esto haría que fuese el único «rito de victoria» que persistiría incluso durante la democracia.

\section{Bibliografía}

Acción Cultural Española. (2014). Esto me trae aqui. Ricardo de Orueta (1868-1939): En el frente del arte. Madrid: Acción Cultural Española.

Agapito y Revilla, J. (1913). Tradiciones de Valladolid: una estatua que habla. Boletin de la Sociedad Castellana de Excursiones, 136, 364-366.

Alares López, G. (2011). La conmemoración del milenario de Castilla en 1943: historia y espectáculo en la España franquista. Revista de Historia Jerónimo Zurita, 86, 149-180.

- (2016). The Milennial of Castile (1943): the historical culture of Spanish fascism. European Review of History/Revue européenne d'histoire, 23 (4), 707-723. Disponible en: https://doi.org/10.1080/13507486.2016.1154930.

Amigo Vázquez, L., Diez Abad, M. R. y López Gallegos, S. (2007). Un sueńo frustrado: la creación de la Casa de Valladolid en Madrid, 1944-6. Investigaciones Históricas. Épocas modernas y contemporáneas, 27, 209-230.

Arco Blanco, M. A. del (2007). Hambre de siglos: mundo rural y apoyos sociales del franquismo en Andalucia Oriental (1936-51). Granada: Comares.

Barberán, C. (1948). Museo Nacional de Escultura de Valladolid. Madrid: Guias Afrodisio Aguado.

Barreiro López, P. (2014). Reinterpreting the Past: The Baroque Phantom during Francoism. Bulletin of Spanish Studies, 91 (5), 715-734.

— Kasten, C. y Locker, T. (eds.). (2014). The Baroque in the Construction of a National Culture in Francoist Spain. Special Issue Bulletin of Spanish Studies, 91 (5), 657-671. Disponible en: https://doi.org/10.1080/14753820.2014.908566.

Barthes, R. (2009) [1957]. Mythologies. London: Vintage.

Besançon, A. (2000). The Forbidden Image: An Intellectual History of Iconoclasm, trans. Jane Marie Todd. Chicago: University of Chicago Press.

Bolaños, M. (2013). Ricardo de Orueta, crónica de un olvido. Revista de la Subdirección General de Museos Estatales, 9, 180-189.

Box, Z. (2004). Secularizando el Apocalipsis: manufactura mítica y discurso nacional franquista: la narración de la Victoria. Historia y Politica, 12, 133-160. (2010). España año cero: la construcción simbólica del franquismo. Madrid: Alianza.

— y Saz, I. (2011). Spanish Fascism as a Political Religion (1931-1941). Politics, Religion and Ideology, 12 (4), 371-389. Disponible en: https://doi.org/10.1080/21567689.20 11.624408 .

Bray, X. et al. (2009). The Sacred Made Real: Spanish Painting and Sculpture, 1600-1700. London: National Gallery.

Burrieza Sánchez, J. (2004). Cinco siglos de cofradias y procesiones: historia de la Semana Santa en Valladolid. Valladolid: Ayuntamiento de Valladolid. 
Cazorla Sánchez, A. (1999). Dictatorship from below: Local Politics in the making of the Francoist State. Journal of Modern History, 71 (4), 882-901. Disponible en: https://doi. org/10.1086/235362.

- (2000). Las políticas de la victoria: la consolidación del Nuevo Estado franquista, 193853. Madrid: Marcial Pons.

Christian, W. A. (1989). Local Religion in Sixteenth-Century Spain. Princeton: Princeton University Press.

- (2012). Divine Presence in Spain and Western Europe 1500-1960. Budapest: Central European University Press.

Cossío, F. (1939). Manolo. Valladolid: Santarem.

— (1948). Pregón de la Semana Santa de Valladolid. Valladolid: Junta de Semana Santa.

- (1959). Confesiones: Mi familia, mis amigos y mi época. Madrid: Espasa Calpe.

El Museo Nacional de Escultura, Valladolid. (1933). Madrid: Centro de Estudios Históricos.

Febo, G. di. (2002). Ritos de guerra y de victoria en la España Franquista. Bilbao: Desclée de Brouwer.

- (1987). La Santa de la Raza: Teresa de Avila, un culto barroco en la España franquista. Barcelona: Icaria Editorial.

Franco Bahamonde, F. (1943). Palabras del Caudillo: 19 abril 1937-7 diciembre 1942. Madrid: Editorial Nacional.

Gavilán Domínguez, E. (2005). El hechizo de Samana Santa: sobre el lado treatral de las procesiones de Valladolid. Trama y Fondo, 18, 7-31.

García Chico, E. (1949). Juan de Juni. Valladolid: Escuela de Artes y Oficios Artísticos de Valladolid.

- (1952). Gregorio Fernández. Valladolid: Escuela de Artes y Oficios Artísticos de Valladolid.

Guia [de] Semana Santa: Valladolid (1940).

Hernández Burgos, C. (2011). Granada azul: La construcción de la 'Cultura de la Victoria' en el primer franquismo, 1936-1951. Granada: Comares.

- (2015). De la cultura de guerra a la cultura de la victoria: los vencedores y la construcción de la dictadura franquista, 1936-1951. Pasado y Memoria, 15, 123-148.

Junta Pro-fomento de la Semana Santa (1947). Guía oficial de la Semana Santa en Valladolid: imaginería castellana. Valladolid: Gerper.

Lipari, S. (2014). Pasos y Pregones, imágenes y palabras. Humanities, 3 (6), 173-193.

Locker, T. (2014). The Baroque in the construction of a national culture in Francoist Spain: An introduction. Bulletin of Spanish Studies, 91 (5), 657-671. Disponible en: https:// doi.org/10.1080/14753820.2014.908564.

Martín Abril, F. J. (1969). Crónica desordenada. Madrid: Editorial Nacional.

Martín Jiménez, I. (2000). La Guerra Civil en Valladolid, 1936-9: amaneceres ensangrentados. Valldolid: Ámbito.

Moreno, I. (1985). Cofradias y hermandades andaluzas: estructura, simbolimso e identidad. Sevilla: Ediciones Andaluces Unidas.

Ors, E. d'. (1944). Lo barroco. Madrid: Aguilar.

Ortiz Echagüe, J. (1943). España mistica. Madrid: Bolaños y Aguilar. 
Palomares Ibáńez, J. M. (2001). La guerra civil en la ciudad de Valladolid: entusiasmo y represión en la 'capital del alzamiento'. Valladolid: Universidad de Valladolid. (2002). El primer franquismo en Valladolid. Valladolid: Universidad de Valladolid.

Pasos restaurados. (2000). Valladolid: Museo Nacional de la Escultura.

Pérez López, P. (1994). Católicos, politica e información: Diario Regional de Valladolid, 19311980. Valladolid: Universidad de Valladolid.

Primo de Rivera, P. (1983). Recuerdos de una vida. Madrid: Drysa.

Preston, P. (2012). The Spanish Holocaust: Inquisition and Extermination in Twentieth-Century Spain. London: HarperCollins.

Richards, M. (2005). «Presenting arms to the Blessed Sacrament»: Civil War and Semana Santa in the city of Málaga, 1936-9. En C. Ealham y M. Richards (coords.). The Splintering of Spain: Cultural History and the Spanish Civil War, 1936-9 (pp. 196-222). Cambridge: CUP. Disponible en: https://doi.org/10.1017/CBO9780511497025.013.

Richmond, K. (2003). Women and Spanish Fascism: The Women's Section of the Falange, 1934-59. London and New York: Routledge. Disponible en: https://doi.org/10.4324/ 9780203380727.

Rina Simón, C. (2015a). La construcción de los imaginarios franquistas y la religiosidad 'popular', 1931-1945. Badajoz: Diputación de Badajoz.

- (2015b) La experiencia de Dios en el Nuevo Estado: militarización y fascitización de la Semana Santa, 1936-45. Amnis. Revue de civilization contemporaine Europes/Amériques, 14. Disponible en: https://amnis.revues.org/2670\#text.

Rodrigo Sánchez, J. (2014). Guerreros y teólogos. Guerra santa y martirio fascista en la literatura de la cruzada del 36. Hispania, 247, 555-586. Disponible en: https://doi. org/10.3989/hispania.2014.018.

Rodríguez Becerra, S. (2000). Religión y fiesta: antropología de las creencias y rituales en Andalucía. Sevilla: Signatura.

Sánchez Hererro, J. (1992). Las cofradías de Semana Santa de Sevilla entre 1875 y 1990. En L. Álvarez Rey et al. Las cofradias de Sevilla en el siglo XX (pp. 45-124). Sevilla: Universidad de Sevilla.

Spiegel, G. (2002). Memory and History: Liturgical Time and Historical Time. History and Theory, 41 (2), 149-162. Disponible en: https://doi.org/10.1111/0018-2656.00196.

Thomas, M. (2013). The Faith and the Fury: Popular Anticlerical Violence and Iconoclasm in Spain, 1931-1936. Brighton: Sussex Academic Press.

Tranche, R. y Sánchez-Biosca, V. (2002). NO-DO: El tiempo y la memoria. Madrid: Cátedra, Filmoteca Española.

Vincent, M. (2007). Spain, 1833-2002: People and State. Oxford: Oxford University Press. (2009). Expiation as Performative Rhetoric in National-Catholicism: The Politics of Gesture in Post-Civil War Spain. Past and Present, 203 (4), 235-256. Disponible en: https://doi.org/10.1093/pastj/gtp011.

- (2015). Ungodly Subjects: Protestants in National-Catholic Spain, 1939-1953. European History Quarterly, 45 (1), 108-131. Disponible en: https://doi.org/10.1177/ 0265691414552782.

Walker Bynum, C. (2011). Christian Materiality: An Essay on Religion in Late Medieval Europe. New York: Zone. 